Full length Article

\title{
Composition and genesis of ferromanganese deposits from the northern South China Sea
}

\author{
Yi Zhong a,b, Zhong Chen ${ }^{\text {a,* }}$, Francisco Javier González ${ }^{c}$, James R. Hein ${ }^{\text {d }}$, Xufeng Zheng a , Gang Li ${ }^{\text {a }}$, \\ Yun Luo ${ }^{\mathrm{a}, \mathrm{c}}$, Aibin Mo ${ }^{\mathrm{a}, \mathrm{c}}$, Yuhang Tian ${ }^{\mathrm{a}, \mathrm{c}}$, Shuhong Wang ${ }^{\mathrm{a}}$ \\ ${ }^{a}$ CAS Key Laboratory of Marginal Sea Geology, South China Sea Institute of Oceanology, Chinese Academy of Sciences, Guangzhou 510301, China \\ ${ }^{\mathrm{b}}$ University of Chinese Academy of Sciences, Beijing 100049, China \\ ${ }^{\mathrm{c}}$ Marine Geology Dv., Geological Survey of Spain (IGME), Madrid 28003, Spain \\ ${ }^{\mathrm{d}}$ U.S. Geological Survey, 2885 Mission St., Santa Cruz, CA 95060, USA
}

\section{A R T I C L E I N F O}

\section{Article history:}

Received 4 November 2016

Received in revised form 6 February 2017

Accepted 6 February 2017

Available online 9 February 2017

\section{Keywords:}

Fe-Mn deposits

Genetic model

Rare earth elements

Hydrogenetic-diagenetic growth

Hydrocarbon seeps

Northern South China Sea

\begin{abstract}
A B S T R A C T
Marine ferromanganese (Fe-Mn) nodules and crusts are archives of past environmental conditions and potential mineral resources. Over the last 30 years, many have been discovered in the northern South China Sea (SCS). To determine the origin of the Fe-Mn deposits, a comprehensive laboratory analysis of physical properties, mineralogy and geochemistry was conducted on newly collected Fe-Mn nodule/crust samples. The results revealed that there are three types of Fe-Mn deposits: (1) Fe-rich nodules containing essentially goethite occur on the northeastern slope of the SCS, with high Fe, low Mn $(\mathrm{Mn} / \mathrm{Fe}=0.03)$ and low trace metals and rare earth elements concentrations; (2) Smooth Fe-Mn nodules and crusts composed of asbolane, todorokite and CFA occur along the northwestern marginal of the SCS that have similar Fe and Mn contents $(\mathrm{Mn} / \mathrm{Fe}=1.21)$, moderate trace metal enrichments, and a positive Ce anomaly; (3) FeMn nodules and crusts composed of asbolane, todorokite and birnessite that occur in the central basin of the SCS have higher $\mathrm{Mn}$ and lower Fe contents ( $\mathrm{Mn} / \mathrm{Fe}=1.45)$. This depositional pattern was associated with major changes in oceanographic conditions and tectonic regimes. The northeastern slope deposits occur in a contourite depositional system, are strongly enriched in Fe relative to Mn (average 38.7\% and $0.96 \%$, respectively), formed from the combination of hydrogenetic and diagenetic processes. We propose a new genetic model for Fe-Mn nodules, which formed through the oxidation of pyrite and pyritebarite concretions that formed by rapid early diagenetic growth (average $3320 \mathrm{~mm} / \mathrm{Myr}$ ) on continental margins above the carbonate compensation depth, and dominated by hydrocarbon seep structures and strong erosive action of bottom currents along the northeastern slope. In contrast, the introduction of vigorous deep-water flow from the North Pacific promoted the slow growth (4-7 mm/Myr) of hydrogenetic Fe-Mn nodules and crusts along the northwestern margin. Finally, hydrogenetic growth of Fe-Mn nodules and crusts in the central basin may have been enhanced by volcanic processes. Our data provide new insights into the genesis and province characteristics of the Fe-Mn nodules and crusts of the northern SCS.

(c) 2017 Elsevier Ltd. All rights reserved.
\end{abstract}

\section{Introduction}

Ferromanganese (Fe-Mn) deposits are metal-rich chemical sediments that are potential archives for geological and environmental changes and are potential mineral resources (Ling et al., 1997; Ren et al., 2007). They may contain base metals and strategic and

\footnotetext{
* Corresponding author.

E-mail addresses: zhongyi@scsio.ac.cn (Y. Zhong), chzhsouth@scsio.ac.cn (Z. Chen), fj.gonzalez@igme.es (F.J. González), jhein@usgs.gov (J.R. Hein), zxf@scsio.ac.cn (X. Zheng), gangli@scsio.ac.cn (G. Li), hpu2011luo@163.com (Y. Luo), abmo@scsio.ac.cn (A. Mo), tyh@scsio.ac.cn (Y. Tian), wshds@scsio.ac.cn (S. Wang).
}

critical elements such as $\mathrm{Cu}, \mathrm{Ni}, \mathrm{Zn}, \mathrm{Co}$, rare earth elements (REEs) and are being considered for future mining (Rona, 2008; Hein et al., 2013). Oceanic Fe-Mn deposits include Fe-Mn crusts, also referred as cobalt-rich crusts, polymetallic nodules, and hydrothermal crusts and impregnations. Numerous reviews of Fe-Mn deposits genetic processes and distributions exist (Halbach et al., 1981; Aplin and Cronan, 1985; Hein et al., 1997, 2000, 2013). These deposits are commonly distinguished as hydrogenetic, diagenetic, mixed hydrogenetic-diagenetic or hydrothermal deposits, and are present in many geological and oceanographic settings (Dymond et al., 1984; Bau et al., 2014; Josso et al., in press). The terminology is based on the type of fluid from which the Fe-Mn oxide precipitate. In general, marine Fe-Mn oxide precipitates are defined as 
purely hydrogenetic when all constituents are derived from cold seawater, as diagenetic when all constituents are derived from cold oxic or suboxic sediment porewaters, and as hydrothermal when they precipitate in the vicinity of vent sites from fluids with temperatures higher than ambient bottom waters (Bau et al., 2014; González et al., 2016). However, in many places, Fe-Mn nodules and crusts form through a combination of fluid sources thereby exhibiting a mixed origin, primarily either hydrogeneticdiagenetic or hydrothermal-hydrogenetic (Hein et al., 1997; Baturin et al., 2014; González et al., 2016).

It is widely accepted that Fe-Mn oxides occur in a wide variety of geological settings (abyssal plains, spreading centers, oceanic highs) and marine environments (deep oceans, continental margins, shallow waters, and epicontinental seas) (Cronan, 1977; Glasby et al., 1997; Verlaan et al., 2004; González et al., 2007). Much of the research on Fe-Mn oxides has focused on openocean oxides from areas such as the Clarion-Clipperton Fracture Zone (CCFZ) in the central Pacific Ocean, the Central Indian Ocean Basin and the Peru Basin in the southeastern Pacific Ocean (Rona, 2008; Kuhn et al., 2012). Only a few studies focused solely on continental margin Fe-Mn nodules and crusts, such as from Galicia Bank (NW Atlantic Iberia margin) (González et al., 2016), Gulf of Cadiz (González et al., 2012), California continental-margin (Hein et al., 2005; Conrad et al., in press), Canary Island Seamount Province (Marino et al., in press) and the Philippine Sea (Xu et al., 2006).

The South China Sea (SCS) is one of the largest marginal seas of the western Pacific, it is subject to relatively large terrestrial inputs, metal fluxes from continental shelf and slope hypoxic sediment, seasonal upwelling, high primary productivity, and a welldeveloped oxygen minimum zone (OMZ) (Xie et al., 2003; Chen and Chen, 2006; Milliman and Farnsworth, 2011; Liu et al., 2015). Because of the enormous amount of terrigenous sediment input into marginal seas, $\mathrm{Fe}$ - and $\mathrm{Mn}$-oxide precipitates are easily diluted making it difficult to enrich metals of potential economic interest, and deposits can be buried quickly by sediments (Zhang et al., 2013). For these reasons, it is well known that the Fe-Mn nodules and crusts of the SCS occur in the central basin, far from the continent and with low sedimentation rates (Wang et al., 1986; Bao and Li, 1993). In recent years, Fe-Mn nodules and crusts were occasionally discovered in areas such as the northeastern or northwestern SCS (Lin et al., 2003; Zhang et al., 2012). Available geochemical data for Fe-Mn nodules and crusts are limited, and basin-wide samples from the northern SCS are lacking, which does not allow for an overall understanding of the mechanisms involved in scavenging of metals from seawater and porewater.

This paper presents detailed physical, textural, mineralogical, and geochemical descriptions of Fe-Mn nodule and crust samples recovered from the northern SCS from 2005 to 2013. Combined with recently available mineralogical and geochemical data of FeMn nodules and crusts throughout the northern SCS, we propose provinces, genetic models, and metal sources of the Fe-Mn nodules and crusts. In addition, we present a comparative analysis with other deep-seabed Fe-Mn deposits, shallow-water and continental margin nodules and crusts from other ocean basins and tectonic settings of the world.

\section{Geological and oceanographic framework}

The SCS is tectonically situated at the intersections of the Eurasian, Pacific, and Indo-Australian plates and, thus its geology had been greatly affected by these surrounding lithospheric plates (Fig. 1a). It is characterized by conjugate passive continental margins in both the north and south (Sun et al., 2014). Its bottom topography is very complex, widely variable with several plateaus, troughs, valleys and island reefs. The study area $\left(106-122^{\circ} \mathrm{N}\right.$ and $12-26^{\circ} \mathrm{E}$, Fig. $1 \mathrm{~b}$ ) is located in the northern SCS, which has a broad continental shelf $(<200 \mathrm{~m}$ water depth) and a large deep basin (maximum water depth $>4000 \mathrm{~m}$ ).

Since the Mesozoic, the northern continental margin of the SCS went through a succession of geotectonic regimes and was strongly dissected by eroded deep-marine channels, submarine canyons,

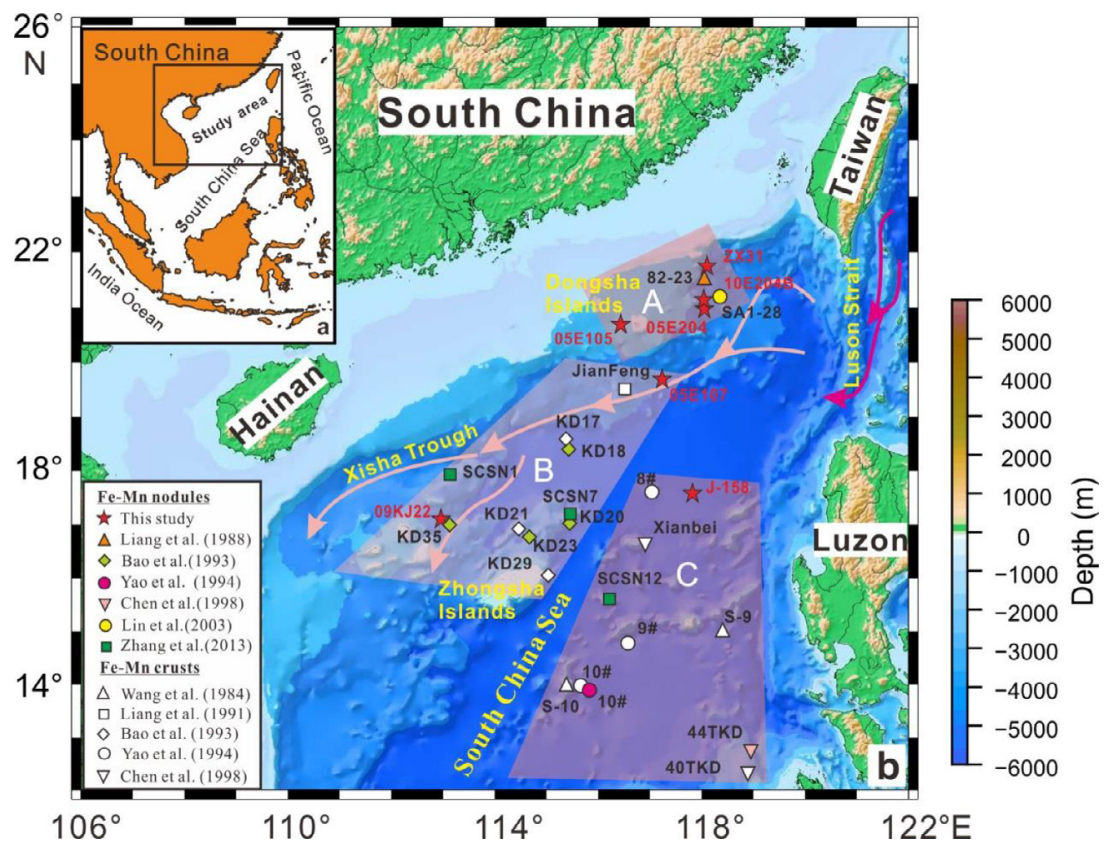

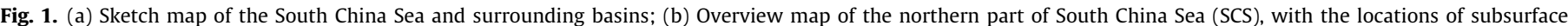

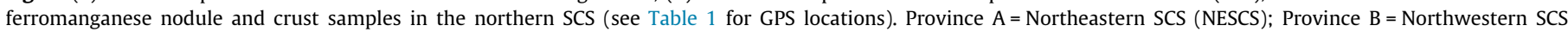

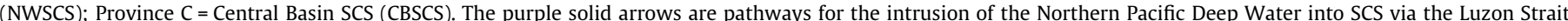

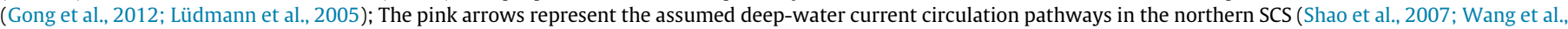
2010; Zheng and Yan, 2012). (For interpretation of the references to color in this figure legend, the reader is referred to the web version of this article.) 
and slope gullies. All of these acted as active conduits for the delivery of clastic sediments from the SCS shelf and upper slope into the deep marine environment (Chiu and Liu, 2008; Gong et al., 2015). Within the study area, the extensional and strike-slip fault system of the Dongsha Islands forms a favorable migration system of fracture conduits or channels through which methane bearing fluids migrate into shallow sediments and vent at the seafloor (Fig. 2a) (Chen et al., 2005). The seafloor seep sites are, in general, characterized by the occurrence of seep carbonates, chemosynthetic benthic communities, tube worms and special topography (such as mud volcanoes, pockmark and mud diapir), which are typical of methane seepage in the modern marine sediments (McDonnell et al., 2000; Ge et al., 2010; Wang et al., 2014).

The central SCS basin is floored primarily by oceanic crust (Taylor and Hayes, 1983; Briais et al., 1993). Cenozoic sedimentary basins controlled by plate motions and tectonic activity, especially by extension and other dynamic events, are roughly parallel to the NE-striking faults (Fig. 2b) (Suo et al., 2014). Structurally and bathymetrically, it is complicated with extinct spreading centers, transform faults, ridges, and late-stage seamount volcanism after the cessation of seafloor spreading (e.g., Yan et al., 2006; Xu et al., 2012). According to its water depth and seafloor topographic features, the SCS basin is confined by the continental-ocean boundary and is subdivided into northwest, east and southwest subbasins (Barckhausen et al., 2014). Especially, the East sub-basin, the largest basin among the three SCS sub-basins, is characterized by many widely distributed seamounts. Based on a limited amount of age data (Wang et al., 1985; Yan et al., 2014), the seamounts generally show a younger trend from the northwest sub-basin to the Huangyandao seamount chain, approximately corresponding to the age of the underlying oceanic crust (Fig. 2b). The approximately E-W-trending Zhenbei-Huangyan seamounts chain is a post-spreading magmatic chain formed after the cessation of seafloor spreading (Tu et al., 1992; Briais et al., 1993; Wang et al., 2009; Xu et al., 2012). Consequently, the igneous rocks from SCS seamounts and volcanoes in the surrounding areas contain a record of the source and evolution of intraplate or post-spreading volcanism that commenced as early as $\sim 18 \mathrm{Ma}$ and is still active at the northern margin of the SCS and in the Indochina block (Wang et al., 1985).

Modern oceanic circulation in the SCS is influenced mainly by the semi-enclosed-basin physiography, the main oceanic water masses, and atmospheric circulation (Qu et al., 2006b; Zhu et al., 2010). It preserves water exchange through straits with the Pacific
Ocean, Indian Ocean, and the adjacent marginal seas (Fig. 1b). In the East Asia region, differential heating between the NW Pacific and the Asian land-mass leads to a seasonal reversal of monsoon winds and resultant seasonal surface circulation patterns over the SCS (Fang et al., 2012). Summer monsoon winds flow weakly from the southwest towards the northeast and vice versa in winter, leading to anticyclonic and cyclonic basin circulation, respectively (Shaw and Chao, 1994). The local bathymetry and stratification of the water column result in Ekman pumping and transport, which are important in generation of summer upwelling of cold, nutrient-rich and high-salinity water offshore SE Vietnam (Dippner et al., 2007; Chen et al., 2012). The upwelled water is transported off shore and nutrient distributions are affected by mixing, biologic, drawdown, and particulate scavenging (Tang et al., 2004).

The Luzon Strait is the only deep connection between the SCS and the North Pacific, with the deepest sill at about $2400 \mathrm{~m}$, located in the Bashi Channel (Wang and Li, 2009; Li and Gong, 2016). Numerous studies of deep-water circulation in the SCS (i.e., below $2000 \mathrm{~m}$ ) have been undertaken to constrain the inflow and the pathway of the North Pacific Deep Water (NPDW) into the SCS (Qu et al., 2006b; Tian et al., 2006; Wang et al., 2011; Zhao et al., 2014). The NPDW, characterized by low temperature $\left(1.6^{\circ} \mathrm{C}\right)$ and high salinity $(34.62 \%)$, sinks into the deep SCS basin immediately after it crosses the Luzon Strait (Fig. 3) (Wyrtki, 1961). The basin-scale oxygen distribution suggests that deep water that enters the SCS is transported north and westward to the northern slope of the SCS and then southward along its western margin (Fig. 1b) (Li and Qu, 2006; Qu et al., 2006a); It enhances vertical mixing and potentially contributes to upper layer circulation (Qu et al., 2006b; Tian et al., 2009). Moreover, a series of NE- and WSW-migrational channels developed on the northern slope (Zhu et al., 2010; He et al., 2013; Li et al., 2013a). Most contourite deposits are linked to bottom water activity, which has $\mathrm{p}$ aleoceanographic/paleoclimatic implications in this area (Chen et al., 2014; Kuang et al., 2014; Gong et al., 2015).

\section{Materials and methods}

\subsection{Sample collection}

As part of the integrated research cruises organized by the South China Sea Institute of Oceanology (SCSIO, Chinese Academy of Sciences) since 2005, 15 Fe-Mn nodule samples were collected
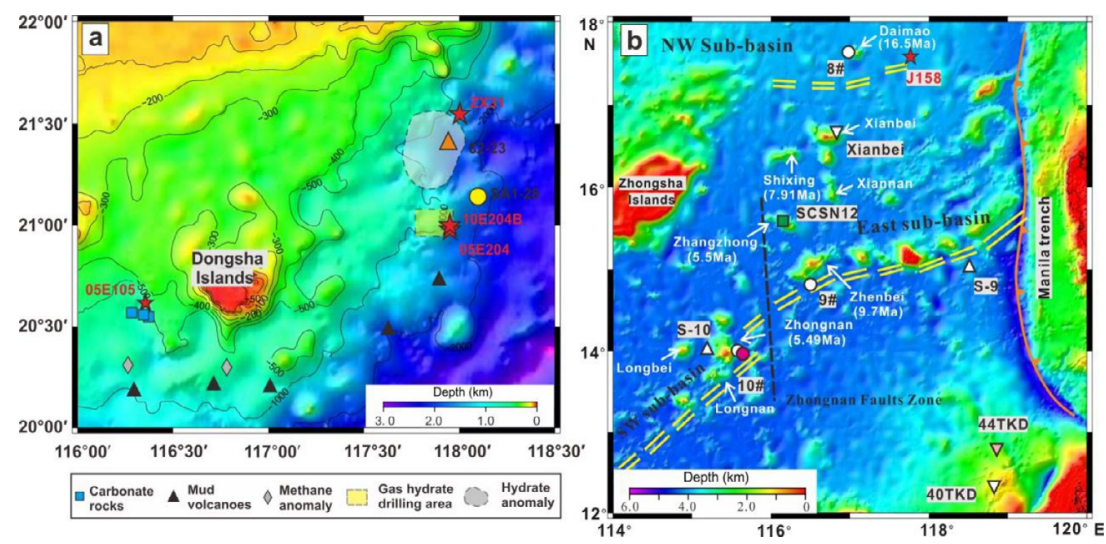

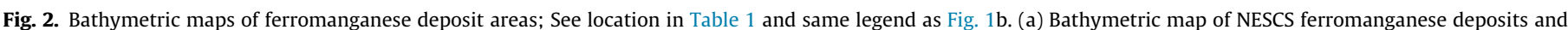

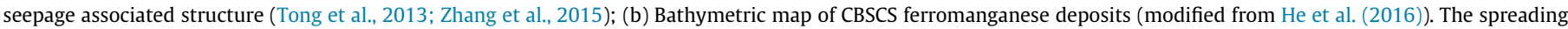

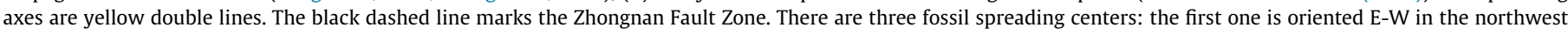

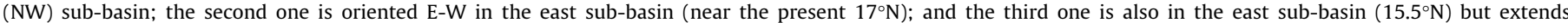

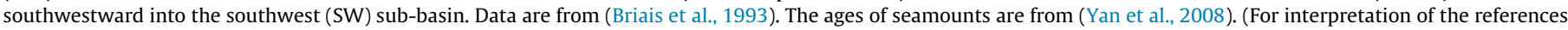
to color in this figure legend, the reader is referred to the web version of this article.) 

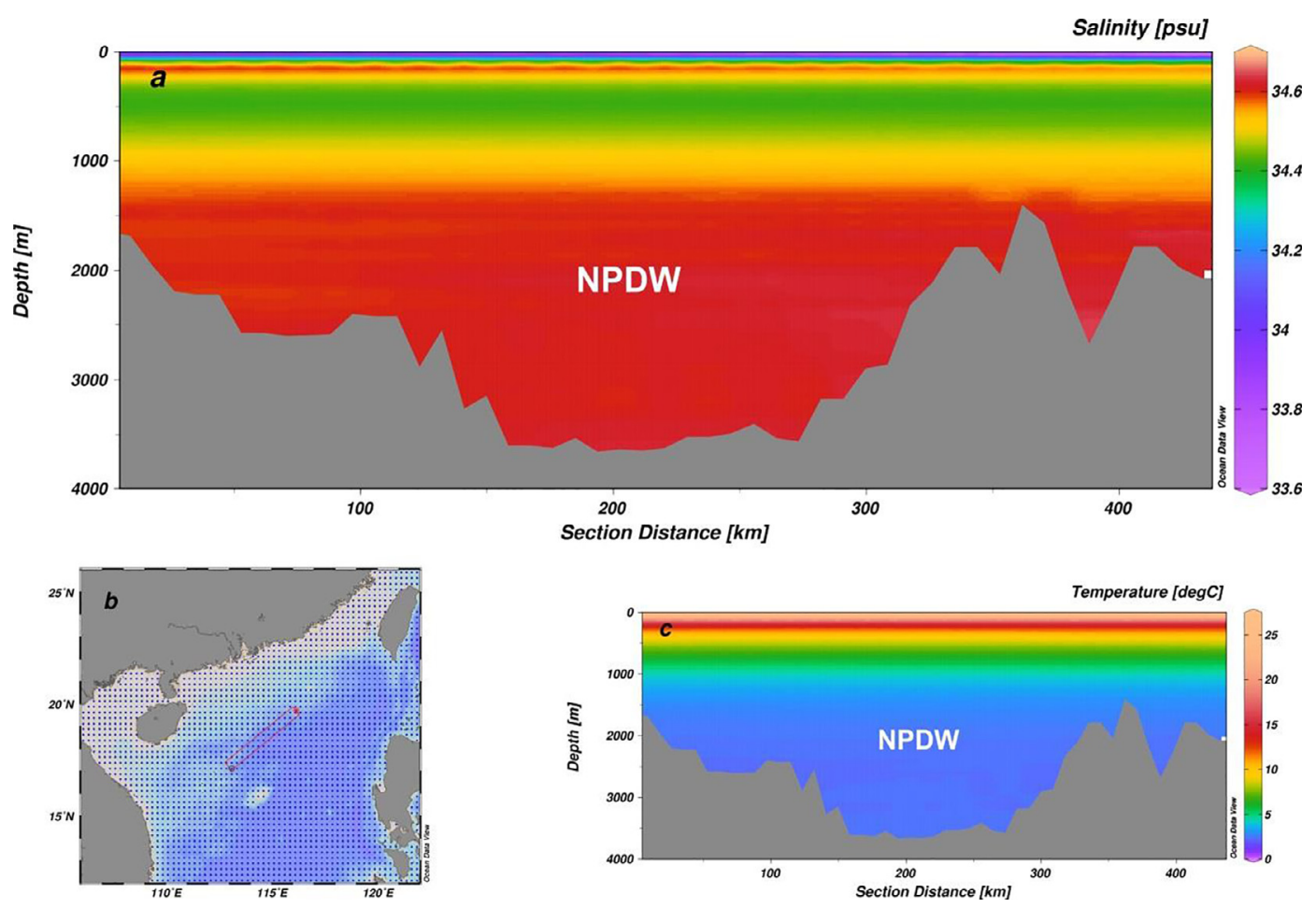

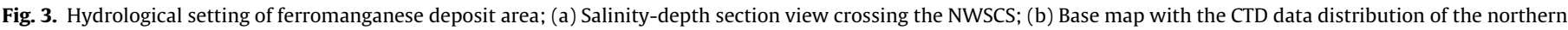
SCS; (c) Temperature-depth section view crossing the study area.

from seven stations in the northern SCS (Table 1, Fig. 1b). Four stations (05E105, 05E204, 10E204B and ZX31) are located in the northeastern South China Sea (NESCS), while two stations (05E107 and 09KJ22) are in the northwestern South China Sea (NWSCS). The final station (J-158) is in the central basin of the South China Sea (CBSCS) and located in $3573 \mathrm{~m}$ water depth on Jiaolong seamount. In addition, we compiled available mineralogical and geochemical data of Fe-Mn nodules and crusts from the northern SCS (Supplement Table A3).

\subsection{Mineralogy}

Mineralogy was performed by X-ray powder diffraction (XRD) and scanning electron microscopy (SEM). The samples were first thoroughly examined by transmitted and reflected light microscopy, and the internal structure and micro-textural features were described, outlined and photographed. The XRD equipment used included a PANalytical X'Pert PRO diffractometer, $\mathrm{Cu}-\mathrm{K} \alpha$ radiation, carbon monochromator and automatic slit (PTRX-004). The analytical conditions for the XRD were: $\mathrm{CuK} \alpha$ radiation at $40 \mathrm{kV}$ and $30 \mathrm{~mA}$, a curved graphite secondary monochromator, scans from 2 to $70(2 \theta)$, step size of $0.0170(2 \theta)$ and step time $0.5 \% \mathrm{~min}$. Scanning electron microscopy (SEM-EDS) of morphological and 3D textural mineral characteristics was performed on a Hitachi S-4800 instrument and energy dispersive X-ray (EDX) spectrometer (Oxford X-Max 20); spectra were obtained at $20 \mathrm{kV}$ accelerating voltage, and 2 and $10 \mathrm{nA}$ beam current for the EDX.

\subsection{Geochemistry}

For major, trace and REE analysis, powder samples of Fe-Mn nodules were prepared as follows. The surface layers of the nodules, $3 \mathrm{~mm}$ in thickness, were cut from the 15 samples and approximately $40 \mathrm{mg}$ powder was dried at $105-110^{\circ} \mathrm{C}$ and then placed into a Teflon beakers. After $0.5 \mathrm{ml} \mathrm{HF}, 0.5 \mathrm{ml} \mathrm{HNO}_{3}$ and $1.5 \mathrm{ml}$ of
$\mathrm{HCl}$ were added, the sealed beakers were placed in an electric oven at $180^{\circ} \mathrm{C}$ for about $12 \mathrm{~h}$. After cooling, the beakers were heated on a hot plate to dryness, after which $1 \mathrm{ml}$ of $\mathrm{HNO}_{3}$ and $1 \mathrm{ml}$ of $\mathrm{H}_{2} \mathrm{O}$ were added. The beaker was again sealed and placed in an electric oven at $150{ }^{\circ} \mathrm{C}$ for about $12 \mathrm{~h}$ to dissolve the residue. Major elements were determined using a Thermo-Fisher IRIS II Intrepid XSP ICP-OES. Trace elements and REEs were determined using a Perkin-Elmer ELAN 9000 ICP-MS. All the samples were analyzed at the Institute of Oceanology, Chinese Academy of Sciences (IOCAS).

The sensitivity of the instrument was adjusted to about 30,000 cps (counts per second) for $1 \mathrm{ng} / \mathrm{ml}{ }^{115} \mathrm{In}$. Analysis of the reference materials (GBW07315, GBW07316, BCR-2, BHVO-2, GBW0725, GBW07296, NOD-P-1 and NOD-A-1) which are either sediment, basalt or manganese nodules, gave results typically within $\pm 10 \%$ of certified values. Analytical precision, given as the relative standard deviation (RSD), was determined by duplicate analyses of several samples and was typically better than $5 \%$.

In this study, $\mathrm{Ce} / \mathrm{Ce}^{*}=2 \mathrm{Ce}_{\mathrm{SN}} /\left(\mathrm{La}_{\mathrm{SN}}+\mathrm{Pr}_{\mathrm{SN}}\right), \mathrm{Ce}_{\text {anomaly }}=\log \left(\mathrm{Ce}_{\mathrm{SN}} /\right.$ $\left(e_{S N}^{*}\right)$, and $\mathrm{Eu}_{\mathrm{SN}} / \mathrm{Eu}_{\mathrm{SN}}^{*}=2 \mathrm{Eu}_{\mathrm{SN}} /\left(\mathrm{Sm}_{\mathrm{SN}}+\mathrm{Gd}_{\mathrm{SN}}\right)$, where SN refers to normalization of concentration against the Post Archean Australian Shale (PAAS; McLennan, 1989). Discrimination plots used PAAS normalized REY data with $\mathrm{Ce}^{*}=0.5 \mathrm{La}_{\mathrm{SN}}+0.5 \mathrm{Pr}_{\mathrm{SN}}$ or if $\mathrm{Pr}$ data were unavailable $\mathrm{Ce}^{*}=0.67 \mathrm{La}_{\mathrm{SN}}+0.33 \mathrm{Nd}_{\mathrm{SN}}$; plots are $\mathrm{Ce}_{\mathrm{SN}} / \mathrm{Ce}_{\mathrm{SN}}^{*} \mathrm{vs}$ $\mathrm{Nd}$ and $\mathrm{Ce}_{\mathrm{SN}} / \mathrm{Ce}_{\mathrm{SN}}^{*}$ vs $\mathrm{Y}_{\mathrm{SN}} / \mathrm{Ho}_{\mathrm{SN}}$ (Bau et al., 2014) to further confirm that the samples used for comparison are hydrogenetic or diagenetic.

The growth rates of Fe-Mn nodules and crusts were calculated using an empirically derived cobalt chronometer: growth rate $(\mathrm{GR})=0.68 /\left(\mathrm{Co}^{\mathrm{n}}\right)^{1.67}$, where $\mathrm{Co}^{\mathrm{n}}=\mathrm{Co} \times(50 / \mathrm{Fe}+\mathrm{Mn})$, with $\mathrm{Co}, \mathrm{Fe}$, and $\mathrm{Mn}$ expressed as weight percent (wt.\%) (Manheim and LaneBostwick, 1988). One limitation of this method is that the equation does not take into account possible hiatuses during the accretion process. Therefore, the calculated rates represent maximum values and the derived age minimum values (Hein et al., 1990). 
Table 1

Location, setting, and description of ferromanganese nodules and crusts from northern South China Sea.

\begin{tabular}{|c|c|c|c|c|c|c|c|c|}
\hline Location & Longitude & Latitude & $\operatorname{Depth}(\mathrm{m})$ & Types & Substrate & Morphology & Mineralogy & Reference \\
\hline \multicolumn{9}{|c|}{ Northeastern SCS (Province A) } \\
\hline 05E105 & $116^{\circ} 21.543^{\prime}$ & $20^{\circ} 37.256^{\prime}$ & 472 & Nodule & Siliceous ooze & Irregular to spherical & $\begin{array}{l}\text { Goethite, quartz, clay } \\
\text { minerals, CFA }\end{array}$ & This study \\
\hline 05E204 & $117^{\circ} 57.087^{\prime}$ & $20^{\circ} 59.130^{\prime}$ & 1370 & Nodule & Siliceous ooze & $\begin{array}{l}\text { Cylindrical and } \\
\text { spherical }\end{array}$ & $\begin{array}{l}\text { Goethite, barite, pyrite, } \\
\text { quartz and clay minerals }\end{array}$ & \\
\hline 10E204B & $117^{\circ} 57.3142^{\prime}$ & $21^{\circ} 0.1629^{\prime}$ & 1331 & Nodule & Siliceous ooze & $\begin{array}{l}\text { Irregular and } \\
\text { cylindrical }\end{array}$ & $\begin{array}{l}\text { Goethite, quartz, clay } \\
\text { minerals }\end{array}$ & \\
\hline ZX31 & $118^{\circ} 0.59^{\prime}$ & $21^{\circ} 32.79$ & 1000 & Nodule & Siliceous ooze & $\begin{array}{l}\text { Rodlike, irregular and } \\
\text { cylindrial }\end{array}$ & $\begin{array}{l}\text { Goethite, barite, quartz, } \\
\text { clay minerals }\end{array}$ & \\
\hline SA1-28 & $118^{\circ} 16^{\prime}$ & $21^{\circ} 11^{\prime}$ & 2000 & Nodule & Siliceous ooze & Concretion and rodlike & $\begin{array}{l}\delta \mathrm{MnO}_{2} \text {, goethite, quartz, } \\
\text { clay minerals }\end{array}$ & Lin et al. (2003) \\
\hline $82-23$ & $118^{\circ} 0.07^{\prime}$ & $21^{\circ} 31.12^{\prime}$ & 1656 & Nodule & Siliceous ooze & Concretion and rodlike & $\begin{array}{l}\text { Sodium manganite and } \\
\text { todorokite }\end{array}$ & Liang et al. (1988) \\
\hline \multicolumn{9}{|c|}{ Northwestern SCS (Province B) } \\
\hline 05E107 & $117^{\circ} 09.528^{\prime}$ & $19^{\circ} 46.430^{\prime}$ & 2255 & Nodule & Siliceous ooze & Spherical & $\begin{array}{l}\text { Todorokite, birnessite, } \\
\text { quartz, albite }\end{array}$ & This study \\
\hline $09 \mathrm{KJ} 22$ & $112^{\circ} 59.716^{\prime}$ & $17^{\circ} 1.591^{\prime}$ & 1501 & Nodule & Siliceous ooze & Spherical & $\begin{array}{l}\text { CFA, asbolane, todorokite, } \\
\text { birnessite, barite }\end{array}$ & \\
\hline SO4-1DG & $113^{\circ} 05.3857^{\prime}$ & $17^{\circ} 54.9122^{\prime}$ & 1700 & Nodule & Siliceous ooze & $\begin{array}{l}\text { Spherical, kidney, } \\
\text { irregular }\end{array}$ & $\begin{array}{l}\text { Vernadite,quartz,chlorite, } \\
\text { illite,albite }\end{array}$ & Zhang et al. (2013) \\
\hline SO4-7DG & $115^{\circ} 24^{\prime}$ & $17^{\circ} 03^{\prime}$ & 1200 & Nodule & Siliceous ooze & Spherical, irregular & $\begin{array}{l}\text { Quartz, Vernadite, } \\
\text { plagioclase and calcite }\end{array}$ & \\
\hline KD18 & $115^{\circ} 21^{\prime}$ & $18^{\circ} 28^{\prime}$ & 3400 & Nodule & Siliceous ooze & $\begin{array}{l}\text { Spherical, tabular and } \\
\text { irregular }\end{array}$ & $10 \AA$ manganates, $\delta \mathrm{MnO}_{2}$ & Bao and Li (1993) \\
\hline KD20 & $115^{\circ} 24^{\prime}$ & $17^{\circ} 01^{\prime}$ & 1070 & Nodule & Siliceous ooze & $\begin{array}{l}\text { Spherical, tabular and } \\
\text { irregular }\end{array}$ & $10 \AA$ manganates, $\delta \mathrm{MnO}_{2}$ & \\
\hline KD23 & $114^{\circ} 36^{\prime}$ & $16^{\circ} 46^{\prime}$ & 1400 & Nodule & Siliceous ooze & $\begin{array}{l}\text { Spherical, tabular and } \\
\text { irregular }\end{array}$ & $10 \AA$ manganates, $\delta \mathrm{MnO}_{2}$ & \\
\hline KD35 & $113^{\circ} 03^{\prime}$ & $17^{\circ} 01^{\prime}$ & 1500 & Nodule & Siliceous ooze & $\begin{array}{l}\text { Spherical, tabular and } \\
\text { irregular }\end{array}$ & $10 \AA ̊$ manganates, $\delta \mathrm{MnO}_{2}$ & \\
\hline KD17 & $115^{\circ} 21^{\prime}$ & $18^{\circ} 54^{\prime}$ & 2470 & Crust & Siliceous ooze & $\begin{array}{l}\text { Tabulate, oolitic } \\
\text { texture on the surface }\end{array}$ & $10 \AA ̊$ manganates, $\delta \mathrm{MnO}_{2}$ & \\
\hline KD21 & $114^{\circ} 23^{\prime}$ & $16^{\circ} 56^{\prime}$ & 2170 & Crust & Siliceous ooze & $\begin{array}{l}\text { Tabulate, oolitic } \\
\text { texture on the surface }\end{array}$ & $10 \AA$ manganates, $\delta \mathrm{MnO}_{2}$ & \\
\hline KD29 & $114^{\circ} 58^{\prime}$ & $16^{\circ} 04^{\prime}$ & 1250 & Crust & Siliceous ooze & $\begin{array}{l}\text { Tabulate, oolitic } \\
\text { texture on the surface }\end{array}$ & $10 \AA ̊$ manganates, $\delta \mathrm{MnO}_{2}$ & \\
\hline \multicolumn{9}{|c|}{ Central Basin SCS (Province C) } \\
\hline $\mathrm{J}-158$ & $117^{\circ} 45.206^{\prime}$ & $17^{\circ} 33.696^{\prime}$ & 3570 & Nodule & Basalt & Spherical & $\begin{array}{l}\text { Birnessite, todorokite and } \\
\text { asbolane }\end{array}$ & This study \\
\hline 40TKD & $118^{\circ} 48.9^{\prime}$ & $12^{\circ} 21.4^{\prime}$ & 1000 & Crust & Volcanic rock & - & $\delta \mathrm{MnO}_{2}$ & Chen and Cui (1998) \\
\hline 44TKD & $118^{\circ} 51.6^{\prime}$ & $12^{\circ} 48.5^{\prime}$ & 1900 & Nodule & Volcanic rock & - & $\delta \mathrm{MnO}_{2}$ & \\
\hline Xianbei & $116^{\circ} 50^{\prime}$ & $16^{\circ} 40^{\prime}$ & 3000 & Crust & Volcanic rock & - & $\begin{array}{l}\text { Manganite and } \delta \mathrm{MnO}_{2} \text {, } \\
\text { feldspar and calcite }\end{array}$ & \\
\hline $8 \#$ & $116^{\circ} 59^{\prime}$ & $17^{\circ} 37^{\prime}$ & 3429 & Crust & Basalt & - & $\begin{array}{l}\text { Todorokite, clay mineral, } \\
\text { feldspar, pyroxene }\end{array}$ & Yao et al. (1986) \\
\hline $9 \#$ & $116^{\circ} 30^{\prime}$ & $14^{\circ} 48^{\prime}$ & 3116 & Crust & Basalt & - & $\begin{array}{l}\text { Todorokite, clay mineral, } \\
\text { feldspar, pyroxene }\end{array}$ & \\
\hline $10 \#$ & $115^{\circ} 35^{\prime}$ & $14^{\circ} 00^{\prime}$ & 3014 & Crust/nodule & Volcanic rock & - & $\begin{array}{l}\text { Todorokite, clay mineral, } \\
\text { feldspar, pyroxene }\end{array}$ & \\
\hline $\mathrm{S}-9$ & $118^{\circ} 30^{\prime}$ & $15^{\circ} 00^{\prime}$ & 1000 & Crust & - & - & - & Wang et al. (1984) \\
\hline$S-10$ & $115^{\circ} 06^{\prime}$ & $14^{\circ} 00^{\prime}$ & 3000 & Crust & - & - & - & \\
\hline Jianfeng & $116^{\circ} 25^{\prime}$ & $19^{\circ} 28^{\prime}$ & 1500 & Crust & Volcanic rock & $\begin{array}{l}\text { Oolitic and kidney } \\
\text { shape }\end{array}$ & $\begin{array}{l}\text { Todorokite, } \delta \mathrm{MnO}_{2} \text {, } \\
\text { bernadite, birnessite }\end{array}$ & Liang et al. (1991) \\
\hline SO4-12DG & $116^{\circ} 09.5602^{\prime}$ & $15^{\circ} 34.3202^{\prime}$ & 1290 & Nodule & Basalt & Irregular shape & $\begin{array}{l}\text { Quartz, vernadite, mica, } \\
\text { calcite, illite, smectite }\end{array}$ & Zhang et al. (2013) \\
\hline
\end{tabular}

\section{Results}

\subsection{Structure and textural features}

The studied nodules in the NESCS show a wide range of sizes, colors and morphologies. The most abundant samples range in size from 2 to $4 \mathrm{~cm}$ and have an ellipsoidal or spherical shape, although there are nodules up to $8 \mathrm{~cm}$ in diameter with a tabular-toirregular shape. The external color of these Fe-Mn nodules ranges from yellow-orange to black, with red-brown being the most usual color (Fig. 4a-c). Some encrusting organisms, such as tubeworms were observed on nodules surface (Fig. 4b). Internally, the nodules show a complex arrangement of layers with indications of oxidation, open fracture discontinuities and beige phosphorite lenses (Fig. 4c).

The nodules of the NWSCS display different morphologies, including tabular, irregular, discoidal, ellipsoidal, with tabular being the most abundant; the surface texture is smooth. Unlike the Fe-rich nodules from the NESCS, the surface color varies between brown and black and the diameter of nodules ranges from 2 to $10 \mathrm{~cm}$. The nodules are characterized by subparallel growth layers around the nucleus (Fig. $4 \mathrm{~d}$ and e). The layers are massive to thinly laminated and the nucleus-layer boundary is diffuse and paler in color than the laminae (Fig. 4e). Discontinuities in 

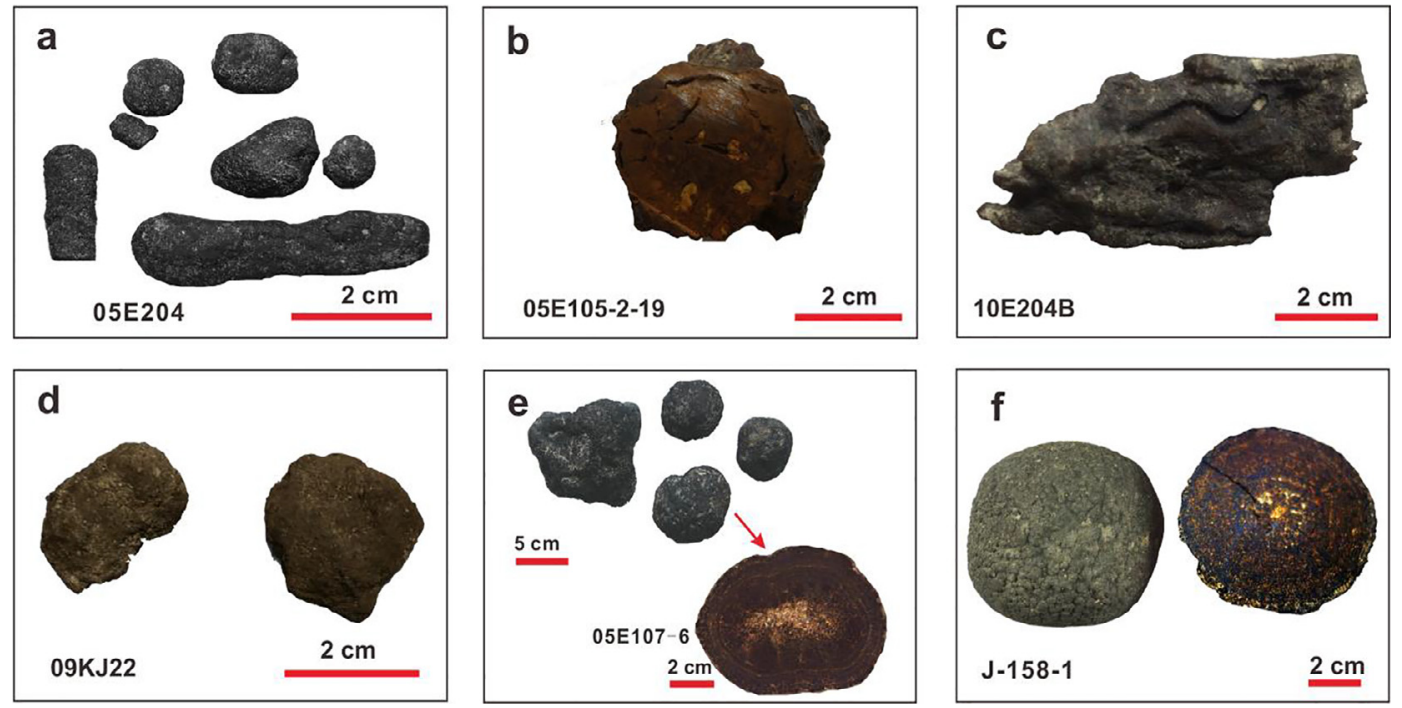

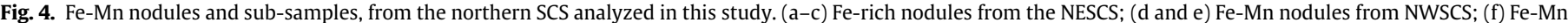
nodule from the CBSCS.

the layers were not observed at the macroscopic level. Coalescence of spheroidal nodules formed sub-spheroidal to tabular nodules.

The J-158 nodule sample in the CBSCS show the same surface colors, sizes, morphologies and internal structure as the NWSCS nodules. The most abundant morphology is ellipsoidal. The surface texture is relatively rough botryoidal and the nodule edges are rounded (Fig. 4f). Mottled textural features were observed internally in some nodule.

\subsection{Mineralogy}

XRD results of the Fe-Mn nodules and crusts are summarized in the Table 1 . The oxyhydroxide minerals show strong overlaps and low crystallinity (Fig. 5). Goethite is the most dominant mineral in all samples from the NESCS. Petrographic and SEM images reveal botryoidal textures and fine aggregates of goethite forming rosettes in groups (Figs. $6 a$ and $7 \mathrm{a}$ and $\mathrm{b}$ ). Other main components of the nodules are: detrital quartz and clay minerals (muscovite, smectites, illite). Clay minerals seem to have two different origins based on SEM images, detrital minerals and authigenic phases (Fig. 7c). Authigenic barite is a main component in nodules from the 05E204 station. Accessory minerals accompanying these major phases include authigenic pyrite and detrital anorthite. Authigenic carbonate fluor-apatite (CFA) and carbonate hydroxyl-apatite are abundant in nodules from the 05E105 station (Fig. 7b). The SEM images show well-developed clusters of idiomorphic authigenic CFA crystals filling foraminifera chambers (Fig. 6d).

The main components of the nodules from the NWSCS are: Mn oxides, barite and CFA as authigenic phases and detrital quartz, albite and phyllosilicates (Fig. $5 \mathrm{c}$ and e). Mn oxides are birnessite (7 Å manganates) and todorokite (10 Å manganates); their characteristic peaks are found in the area of higher spacing and in broadening of the peaks identified in the diffractograms. Birnessite and todorokite show some characteristic peaks at $7.08 \AA$ for bimessite and $9.4 \AA$ for todorokite, with the maximum intensity peak at $4.74 \AA$ A. Minor amounts of asbolane and coronadite, which are usually inter-grown, can also be recognized on XRD. Petrographic SEM images show botryoidal textures in Mn oxides with mineral grain sizes smaller than SEM resolution (Fig. 6b, d and e). Accumulations of carbonate coccolith shells are observed in some nodules. Large clusters of authigenic CFA idiomorphic crystals are common in samples from the 09KJ22 station (Fig. 7h). Dispersed authigenic crystals of barite are seen under the electron microscope (Fig. $7 \mathrm{~g}$ ).
SEM shows bacteria films: (1) micrometer size tubular, helically fibrous structures less than $2 \mu \mathrm{m}$ in diameter, (2) coccoid spheroidal structures, and 3) rod-shape forms covered by Fe-Mn oxides, that may result from the activity of microorganisms (Fig. 6e and f).

The nodule J-158 from the CBSCS is mainly composed of birnessite and todorokite inter-grown with minor amounts of asbolane (Fig. 5f), all forming botryoidal textures under the petrographic and electron microscope (Figs. $6 \mathrm{c}$ and $7 \mathrm{i}$ ). Detrital quartz, anorthite and phyllosilicates (illite and montmorillonite) are also major phases.

\subsection{Geochemistry}

The bulk chemical composition of the Fe-Mn deposits is provided in Table 2. Fe (up to $45.5 \mathrm{wt} . \%$ ) is the most abundant element in the nodules from the NESCS, followed by $\mathrm{Al}, \mathrm{Mg}, \mathrm{P}$ and $\mathrm{Ca}$. Mn contents are very low ( $0.03 \mathrm{wt} . \%)$. The abundance of Al (up to $3.69 \mathrm{wt} . \% \mathrm{Al}_{2} \mathrm{O}_{3}$ ) suggests the presence of clay minerals in the nodules as confirmed by XRD and SEM. The $\mathrm{Mn} / \mathrm{Fe}$ ratios vary from 0.001 to 0.13 with a mean value of 0.03 . Some nodules from the 05E105 station show high $\mathrm{P}_{2} \mathrm{O}_{5}$ contents (up to $3.7 \mathrm{wt} . \%$ ) indicating the abundance of phosphate minerals. The combined $\mathrm{Cu}+\mathrm{Ni}+\mathrm{Co}$ concentration is very low ranging from 0.01 to $0.19 \mathrm{wt} . \%$ with an average of $0.07 \mathrm{wt} . \%$, which is very depleted compared with the mean value for oceanic abyssal nodules (1.4 wt.\%) (Baturin, 1988). Ba, V, Zn, Pb, and $\mathrm{Cr}$ are the most abundant trace metals on the NESCS nodules. The markedly high Ba content in nodule 05E204-1 likely reflects the abundance of barite in detrital grains and authigenic minerals. Nodule 10E204B-1 shows moderate contents of $\mathrm{Ce}, \mathrm{Co}$ and other trace metals, indicating combined genetic processes (diagenesis and hydrogenesis) for this nodule. All Fe-Mn nodules from the NESCS show very low total REE contents $(157.7 \mu \mathrm{g} / \mathrm{g}$ on average) ranging from 29.8 to $441.3 \mu \mathrm{g} / \mathrm{g}$ (Table 2 ). They show a moderate enrichment in light rare earth elements (LREEs) and a negative to slightly positive Ce anomaly (Ce/ $\left.\mathrm{Ce}^{*}=0.88-1.95\right)$ and a positive $\mathrm{Eu}$ anomaly $\left(\mathrm{Eu} / \mathrm{Eu}^{*}=1.08-1.16\right)$. For seven samples of Fe-rich nodules, $\mathrm{P}$ has a positive correlation with $\mathrm{Ca}(0.94)$. The terrigenous elements $\mathrm{Al}, \mathrm{K}, \mathrm{Na}$ and Ti show positive correlations among members of that group (0.6-0.9). Fe exhibits a positive correlation with $\mathrm{Mg}(0.77)$ and a negative correlation with Na (-0.95) (Supplement Table A1).

Bulk average element contents in nodules from the NWSCS show a different pattern. Fe and Mn display similar average con- 

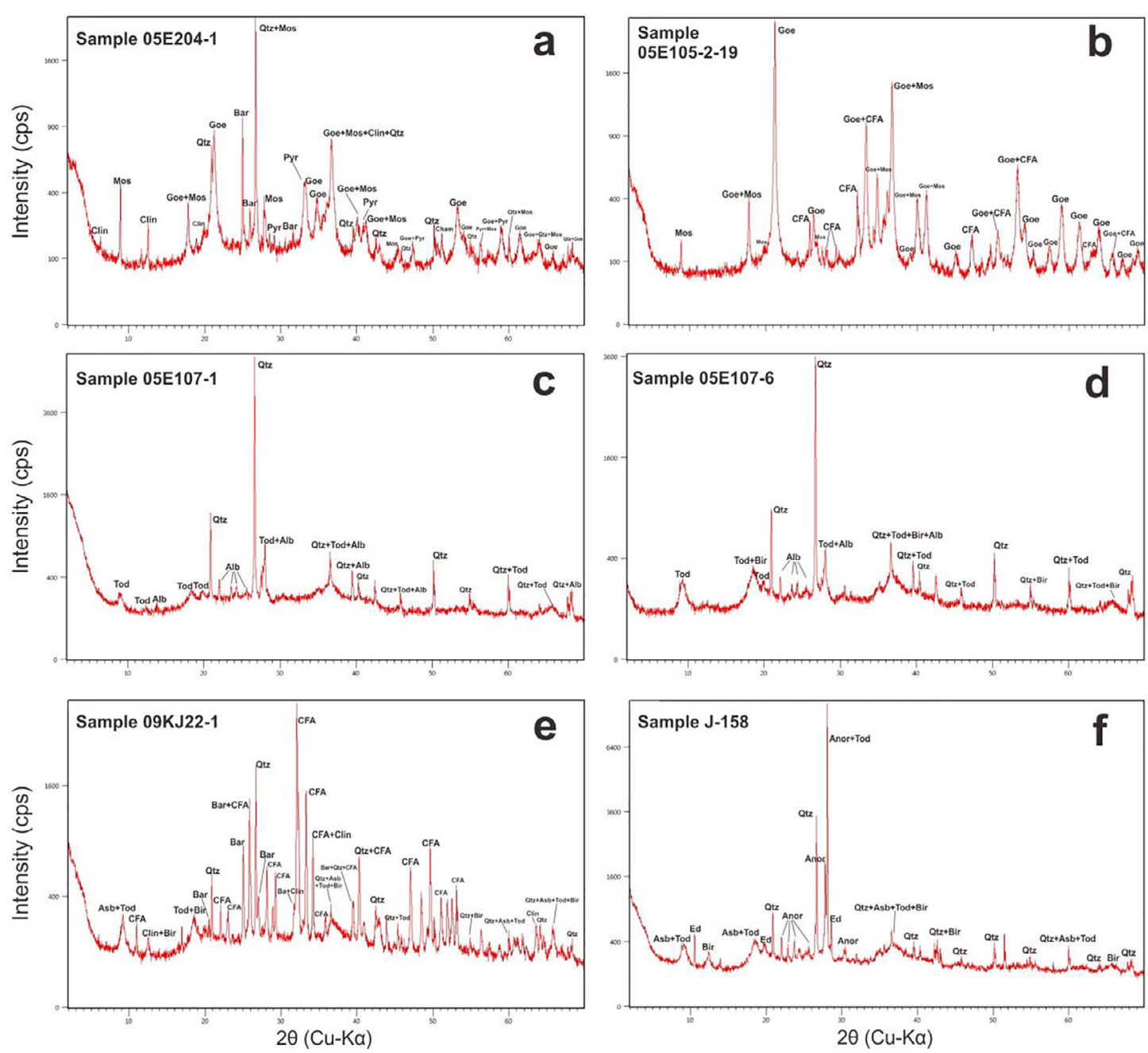

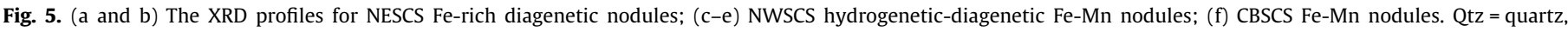

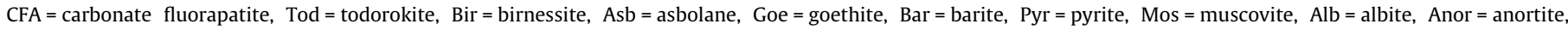
Clin = clinochlore, $\mathrm{Ed}=$ edentite (amphibole).
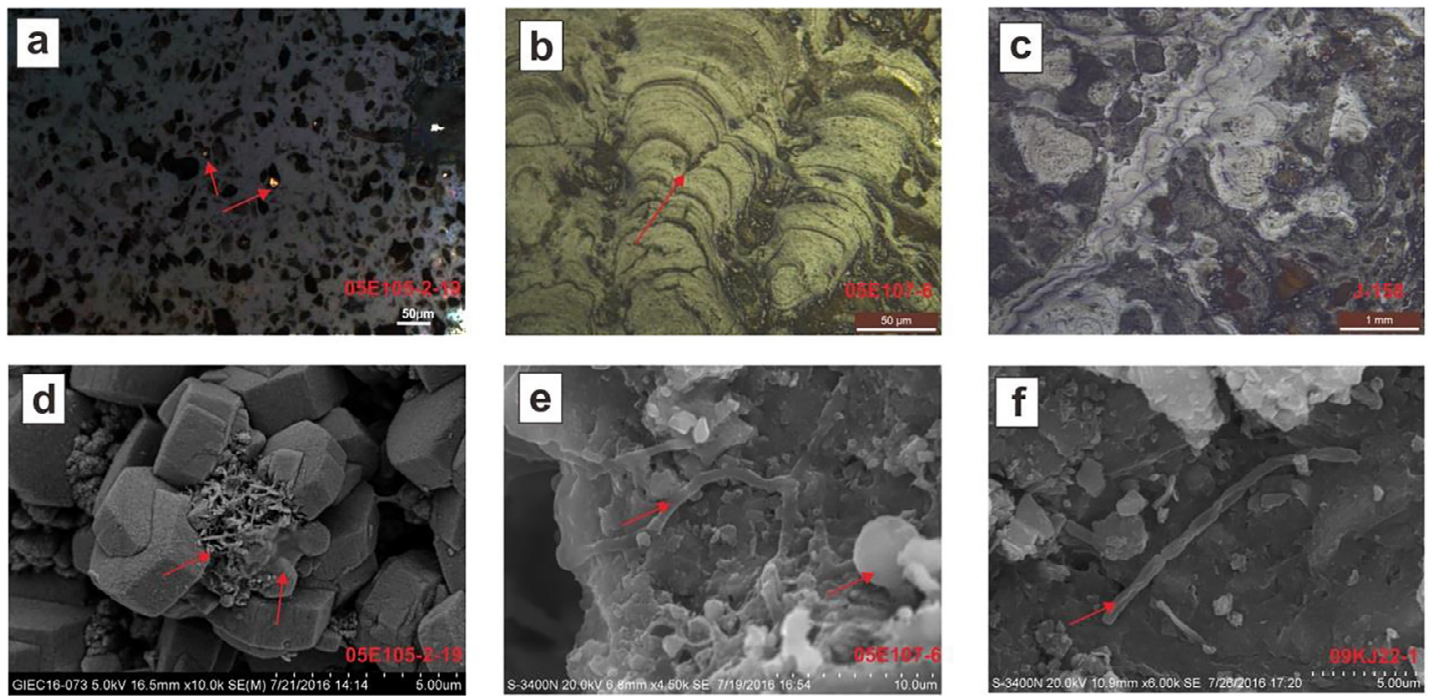

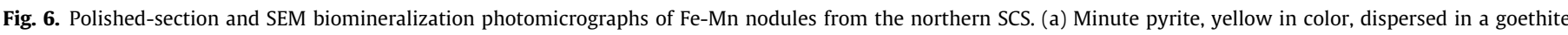

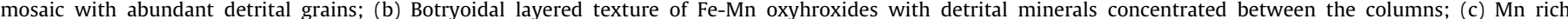

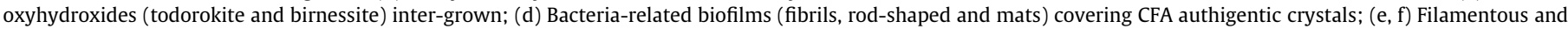

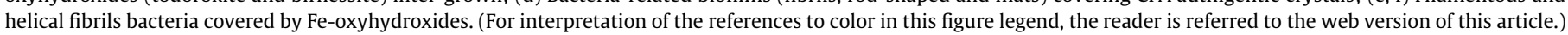



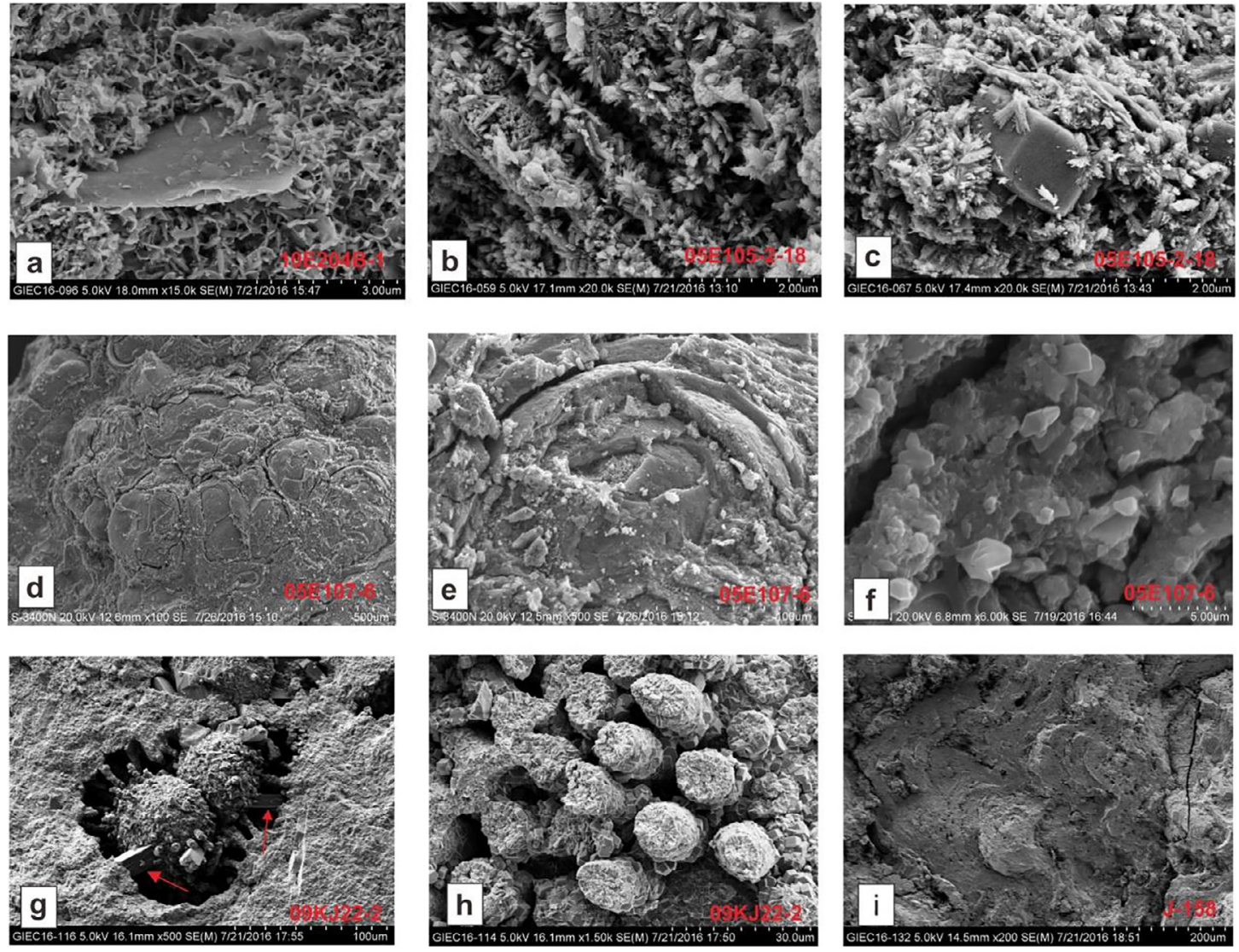

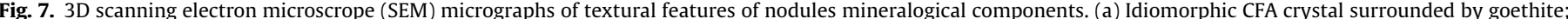

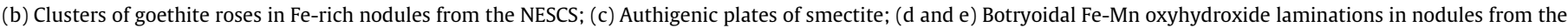

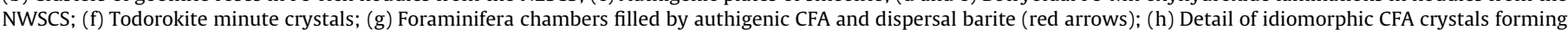

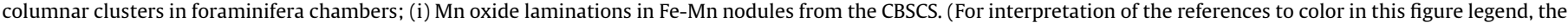
reader is referred to the web version of this article.)

centrations: 12.1 and $14.2 \mathrm{wt} . \%$, respectively. The $\mathrm{Mn} / \mathrm{Fe}$ ratios vary from 0.77 to 1.67 with a mean of 1.21 . The high content of $\mathrm{Al}_{2} \mathrm{O}_{3}$ (up to $5.56 \mathrm{wt} . \%$ ) reflects clay minerals within the nodules. The mean total concentration of $\mathrm{Cu}+\mathrm{Ni}+\mathrm{Co}$ in bulk nodules is $0.72 \mathrm{wt} . \%$, with values ranging from 0.47 to $1.06 \mathrm{wt} . \%$. Two nodules show high $\mathrm{P}_{2} \mathrm{O}_{5}$ concentrations (around $6.5 \mathrm{wt} . \%$ ) indicating the abundance of phosphate minerals. Samples show moderate contents of $\mathrm{TiO}_{2}$ (up to $0.6 \mathrm{wt} . \%$ ). There are also high concentrations of $\mathrm{Ba}, \mathrm{Pb}, \mathrm{Sr}, \mathrm{Zn}$ and $\mathrm{Zr}$ (Table 2). Fe-Mn nodules from the NWSCS show moderate to high REE concentrations ranging from 876.6 to $1378.0 \mu \mathrm{g} / \mathrm{g}$, with positive $\mathrm{Ce}$ and Eu anomalies. For seven $\mathrm{Fe}-\mathrm{Mn}$ nodule samples from this province, the biogenic element $\mathrm{P}, \mathrm{Ca}, \mathrm{Sr}$ and Ba show strong positive correlations among members of that group (>0.95). Fe exhibits a positive correlation with $\mathrm{Ti}(0.97)$ and a negative correlation with $\mathrm{Mn}(-0.93)$. Ca shows a negative correlation with $\mathrm{Al}(-0.96)$ and $\mathrm{Na}(-0.83)$ (Supplement Table A2).

The nodule J-158 collected in the CBSCS has $13.6 \mathrm{wt} . \% \mathrm{Mn}$ and 9.36 wt.\% Fe, with $\mathrm{Mn} / \mathrm{Fe}$ of 1.45 (Table 2). $\mathrm{Al}_{2} \mathrm{O}_{3}$ (8.23 wt.\%) is more abundant than in the nodules collected on the slopes (NESCS and NWSCS). The $\mathrm{Cu}+\mathrm{Ni}+\mathrm{Co}$ concentration is $0.66 \mathrm{wt} . \%$. The most abundant trace metals are $\mathrm{Ba}, \mathrm{Pb}, \mathrm{Zn}$ and $\mathrm{V}$, with high content of $\mathrm{Li}$ $(64 \mu \mathrm{g} / \mathrm{g})$. In the nodule from the CBSCS (J-158), the REE concentrations are moderate $(620.6 \mu \mathrm{g} / \mathrm{g})$ with relatively low Ce $(399 \mu \mathrm{g} / \mathrm{g})$ content, and positive $\mathrm{Ce}\left(\mathrm{Ce} / \mathrm{Ce}^{*}=2.72\right)$ and $\mathrm{Eu}$ anomalies $(\mathrm{Eu} /$ $\left.\mathrm{Eu}^{*}=1.2\right)$. $\mathrm{Y}$ is specially enriched in Fe-Mn samples from the NWSCS and CBSCS relative to the nodules from the NESCS.

All samples are enriched in LREEs compared with heavy rare earth elements (HREEs; LREE/HREE $=5-25$ ), but this enrichment is more apparent in the Fe-Mn nodules from the NWSCS and CBSCS
(LREE/HREE $=12-25)$. PAAS-normalized REE in this study show a flat pattern, indicating that terrigenous material contributes to the REE enrichment (Fig. 10); however, correlations coefficients show that the Fe phase is the predominant host for REE in NWSCS (positive correlation with $\mathrm{Fe}$, and negative correlations with $\mathrm{Al}$ and $\mathrm{Mn})$, and $\mathrm{Mn}$ is the predominant host for REE in the NESCS, with a positive correlation with $\mathrm{Mn}$ and no correlations with $\mathrm{Al}$ or $\mathrm{Fe}$ (Supplement Tables A1 and A2). For other samples from the global ocean, the light REE are depleted relative to the heavy REE.

\subsection{Growth rates}

As most of the samples show Co contents below 0.4 wt.\%, the Co chronometer used was the Manheim and Lane-Bostwick (1988) equation which uses Fe, Mn and Co contents in the samples. The GR in nodules from the northern SCS are variable, ranging from 4.6 to $17,408 \mathrm{~mm} / \mathrm{Myr}$ for nodules from the three areas analyzed here. The Fe-rich nodules from the NESCS have the highest GR (47-17,408 mm/Myr) and an average GR of $3320 \mathrm{~mm} / \mathrm{Myr}$. The average GR in the Fe-Mn nodules from the NWSCS is $7.1 \mathrm{~mm} /$ Myr. Nodule J-158 from CBSCS has a GR of $6.5 \mathrm{~mm} /$ Myr. Diagenetic and hydrothermal Fe-Mn deposits growth rates that can be very fast. For example, Fe-Mn nodules from the Peru Basin have GR up to $250 \mathrm{~mm} / \mathrm{Myr}$ (von Stackelberg, 2000), and up to $24,000 \mathrm{~mm} / \mathrm{Myr}$ for hydrothermal deposits (e.g., Hein et al., 1990). For the hydrothermal deposits and Fe-rich diagenetic nodules formed subsurface, this means that deposit formation was rapid and short lived. 
Table 2

\begin{tabular}{|c|c|c|c|c|c|c|c|c|c|c|c|c|c|c|c|}
\hline $\begin{array}{l}\text { Area } \\
\text { Location }\end{array}$ & $\begin{array}{l}\text { NESCS } \\
05 E 204-1 \\
\end{array}$ & 05Е204-2 & 10E204B-1 & 10E204B-3 & 05E105-2-18 & 05E105-2-19 & ZX31-1 & $\begin{array}{l}\text { NWSCS } \\
\text { 05E107-1 }\end{array}$ & 05E107-3 & 05E107-5 & 05E107-6 & 05E107-7 & $09 \mathrm{KJ} 22-3-1$ & 09КJ $22-3-2$ & $\begin{array}{l}\text { CBSCS } \\
\mathrm{J} 158 \\
\end{array}$ \\
\hline $\mathrm{Fe}$ (wt.\%) & 36.0 & 41.5 & 34.2 & 40.9 & 45.4 & 43.0 & 29.8 & 14.5 & 14.3 & 12.0 & 10.0 & 10.5 & 11.3 & 12.4 & 9.36 \\
\hline $\mathrm{Mn}$ & 1.17 & 0.76 & 4.77 & 0.25 & 0.17 & 0.11 & 0.04 & 12.2 & 12.0 & 16.2 & 18.1 & 18.4 & 14.8 & 16.2 & 14.7 \\
\hline $\mathrm{Al}_{2} \mathrm{O}_{3}$ & 3.27 & 2.10 & 2.09 & 2.35 & 1.85 & 2.21 & 3.69 & 4.64 & 4.54 & 5.00 & 5.56 & 5.00 & 2.57 & 2.73 & 8.23 \\
\hline $\mathrm{CaO}$ & 0.71 & 0.64 & 1.03 & 0.53 & 1.49 & 4.78 & 0.43 & 1.69 & 1.72 & 1.65 & 1.43 & 1.76 & 10.21 & 11.08 & 2.27 \\
\hline $\mathrm{K}_{2} \mathrm{O}$ & 0.59 & 0.30 & 0.39 & 0.45 & 0.34 & 0.47 & 1.37 & 0.80 & 0.80 & 1.02 & 1.16 & 1.06 & 0.80 & 0.90 & 1.19 \\
\hline MgO & 1.36 & 1.76 & 1.72 & 1.47 & 1.93 & 1.85 & 1.50 & 1.73 & 1.79 & 2.33 & 2.58 & 2.43 & 1.62 & 1.86 & 2.90 \\
\hline $\mathrm{Na}_{2} \mathrm{O}$ & 0.62 & 0.45 & 0.81 & 0.38 & 0.27 & 0.31 & 0.87 & 2.23 & 2.05 & 2.11 & 2.01 & 2.18 & 1.82 & 1.90 & 2.38 \\
\hline $\mathrm{P}_{2} \mathrm{O}_{5}$ & 0.92 & 1.73 & 1.53 & 1.13 & 1.46 & 3.70 & 0.50 & 0.61 & 0.63 & 0.53 & 0.42 & 0.49 & 6.59 & 6.68 & 0.36 \\
\hline $\mathrm{TiO}_{2}$ & 0.23 & 0.14 & 0.20 & 0.15 & 0.14 & 0.17 & 0.21 & 0.60 & 0.59 & 0.48 & 0.43 & 0.42 & 0.45 & 0.48 & 0.46 \\
\hline Co $(\mu \mathrm{g} / \mathrm{g})$ & 226.7 & 186.7 & 611.3 & 197.8 & 101.1 & 19.8 & 35.4 & 1647.6 & 1504.8 & 1328.7 & 1533.0 & 1106.0 & 1357.9 & 992.2 & 1190.3 \\
\hline $\mathrm{Ni}$ & 501.1 & 356.9 & 1051.1 & 575.7 & 260.5 & 102.4 & 39.3 & 2766.7 & 3206.2 & 6580.6 & 7582.3 & 8555.0 & 3886.9 & 2883.3 & 4172.5 \\
\hline $\mathrm{Cu}$ & 83.6 & 65.3 & 216.3 & 38.6 & 6.0 & 4.8 & 24.9 & 523.1 & 462.5 & 733.0 & 961.4 & 955.6 & 782.5 & 810.5 & 1199.2 \\
\hline $\mathrm{Zn}$ & 351.1 & 574.6 & 604.4 & 371.7 & 137.3 & 111.2 & 146.7 & 479.6 & 508.5 & 640.8 & 711.7 & 838.1 & 653.5 & 663.3 & 584.2 \\
\hline $\mathrm{Pb}$ & 485.7 & 224.3 & 960.7 & 162.9 & 63.5 & 68.2 & 97.8 & 2218.3 & 2255.3 & 1626.1 & 1279.5 & 1407.1 & 2262.5 & 1953.9 & 885.7 \\
\hline $\mathrm{Ba}$ & 6800.8 & 111.4 & 349.8 & 107.1 & 53.1 & 65.1 & 170.5 & 1005.3 & 1034.9 & 1213.0 & 1327.7 & 1136.1 & 10390.5 & 11139.8 & 1084.2 \\
\hline $\mathrm{Sr}$ & 368.0 & 154.9 & 369.0 & 125.9 & 89.9 & 204.5 & 131.7 & 842.6 & 861.5 & 757.0 & 635.1 & 695.7 & 2539.7 & 2024.4 & 540.1 \\
\hline Mo & 35.3 & 18.4 & 43.8 & 35.7 & 21.2 & 25.6 & 20.7 & 67.6 & 51.3 & 57.8 & 71.1 & 107.7 & 55.2 & 115.2 & 64.6 \\
\hline V & 400.6 & 1099.9 & 1137.4 & 445.4 & 271.4 & 258.8 & 293.1 & 371.9 & 369.5 & 372.6 & 365.0 & 376.3 & 679.8 & 475.5 & 323.2 \\
\hline $\mathrm{Hf}$ & 2.55 & 1.83 & 3.30 & 1.39 & 0.70 & 0.80 & 0.90 & 8.52 & 9.34 & 6.80 & 5.33 & 5.66 & 4.81 & 4.22 & 4.26 \\
\hline $\mathrm{Ta}$ & 0.24 & 0.14 & 0.20 & 0.17 & 0.19 & 0.23 & 0.28 & 0.42 & 0.45 & 0.41 & 0.40 & 0.38 & 0.46 & 0.40 & 0.34 \\
\hline Th & 13.4 & 8.06 & 21.4 & 6.33 & 3.61 & 5.06 & 5.34 & 63.9 & 71.7 & 56.0 & 45.5 & 47.0 & 63.4 & 61.6 & 37.9 \\
\hline U & 4.60 & 2.88 & 4.47 & 3.35 & 5.43 & 9.82 & 8.65 & 5.10 & 4.97 & 4.22 & 3.54 & 4.24 & 8.35 & 7.94 & 2.51 \\
\hline $\mathrm{Cr}$ & 447.0 & 357.2 & 157.3 & 256.9 & 153.5 & 65.9 & 152.3 & 23.9 & 25.5 & 26.7 & 29.6 & 26.3 & 11.5 & 11.1 & 31.6 \\
\hline $\mathrm{Ga}$ & 8.47 & 5.02 & 6.94 & 4.88 & 3.88 & 4.29 & 5.57 & 12.8 & 13.7 & 15.3 & 18.7 & 17.3 & 12.8 & 16.9 & 17.8 \\
\hline $\mathrm{Rb}$ & 31.3 & 14.4 & 17.4 & 23.0 & 20.1 & 23.8 & 51.4 & 24.0 & 25.5 & 32.0 & 38.1 & 33.5 & 15.2 & 14.7 & 36.4 \\
\hline $\mathrm{Zr}$ & 122.9 & 101.5 & 172.2 & 69.8 & 32.8 & 34.0 & 42.4 & 690.8 & 700.7 & 487.8 & 285.7 & 304.6 & 288.5 & 263.3 & 226.7 \\
\hline $\mathrm{Nb}$ & 12.0 & 8.99 & 14.17 & 6.90 & 6.43 & 5.99 & 4.68 & 37.5 & 38.1 & 27.7 & 23.1 & 23.8 & 35.4 & 31.4 & 15.1 \\
\hline Cs & 2.65 & 1.12 & 1.39 & 1.89 & 1.81 & 1.97 & 3.44 & 1.73 & 1.83 & 2.39 & 2.84 & 2.49 & 0.95 & 0.85 & 2.72 \\
\hline $\mathrm{Li}$ & 16.8 & 11.4 & 15.6 & 13.8 & 6.1 & 7.0 & 16.3 & 19.4 & 20.3 & 37.3 & 43.9 & 48.7 & 11.6 & 11.2 & 63.7 \\
\hline Sc & 5.82 & 6.48 & 5.58 & 2.74 & 1.15 & 1.11 & 1.82 & 13.01 & 12.90 & 9.91 & 9.91 & 9.50 & 8.28 & 4.49 & 12.86 \\
\hline $\mathrm{Mn} / \mathrm{Fe}$ & 0.03 & 0.02 & 0.13 & 0.01 & 0.00 & 0.00 & 0.00 & 0.76 & 0.76 & 1.22 & 1.63 & 1.58 & 1.18 & 1.18 & 1.42 \\
\hline GR & 229.8 & 394.4 & 47.0 & 344.0 & 1252.5 & 17408.8 & 3566.3 & 4.55 & 5.18 & 7.03 & 5.46 & 9.88 & 5.97 & 11.78 & 6.46 \\
\hline La & 39.0 & 25.1 & 62.4 & 20.6 & 6.5 & 15.8 & 18.5 & 155.2 & 155.5 & 113.8 & 109.5 & 124.7 & 90.5 & 105.6 & 69.0 \\
\hline $\mathrm{Ce}$ & 110.2 & 74.0 & 252.7 & 45.2 & 11.0 & 41.3 & 31.6 & 796.8 & 882.2 & 640.3 & 546.3 & 561.6 & 810.0 & 1188.0 & 398.9 \\
\hline $\operatorname{Pr}$ & 8.38 & 5.05 & 14.24 & 4.07 & 1.28 & 2.48 & 3.46 & 37.82 & 38.44 & 29.42 & 24.38 & 25.84 & 23.41 & 22.58 & 16.58 \\
\hline $\mathrm{Nd}$ & 33.8 & 20.1 & 57.8 & 16.4 & 5.1 & 10.5 & 13.9 & 158.8 & 160.8 & 125.5 & 103.7 & 108.8 & 92.7 & 87.2 & 69.4 \\
\hline $\mathrm{Sm}$ & 7.33 & 4.57 & 13.16 & 3.47 & 1.04 & 2.21 & 2.86 & 36.20 & 36.13 & 28.71 & 24.03 & 25.48 & 20.93 & 19.75 & 16.00 \\
\hline $\mathrm{Eu}$ & 1.70 & 1.07 & 3.16 & 0.85 & 0.25 & 0.55 & 0.65 & 8.88 & 8.50 & 6.97 & 6.04 & 6.18 & 4.65 & 4.27 & 4.06 \\
\hline $\mathrm{Gd}$ & 7.35 & 4.40 & 12.44 & 3.38 & 1.10 & 2.42 & 2.66 & 35.46 & 35.02 & 27.48 & 22.56 & 24.17 & 23.46 & 22.15 & 15.69 \\
\hline $\mathrm{Tb}$ & 1.06 & 0.73 & 1.96 & 0.54 & 0.19 & 0.42 & 0.44 & 5.51 & 5.18 & 4.23 & 3.43 & 3.70 & 2.97 & 2.82 & 2.44 \\
\hline Dy & 5.25 & 3.88 & 9.89 & 3.13 & 1.14 & 2.57 & 2.47 & 26.97 & 25.19 & 20.73 & 16.61 & 18.73 & 14.03 & 12.94 & 12.30 \\
\hline Y & 24.1 & 19.4 & 41.0 & 17.8 & 10.5 & 20.9 & 12.9 & 85.0 & 81.6 & 62.0 & 51.1 & 60.4 & 51.1 & 60.4 & 76.7 \\
\hline Ho & 1.07 & 0.83 & 2.02 & 0.65 & 0.28 & 0.62 & 0.51 & 5.32 & 4.90 & 3.88 & 3.12 & 3.54 & 2.79 & 2.77 & 2.44 \\
\hline $\mathrm{Er}$ & 2.84 & 2.27 & 5.24 & 1.82 & 0.81 & 1.75 & 1.43 & 13.38 & 11.94 & 9.43 & 7.84 & 9.15 & 7.39 & 7.11 & 6.20 \\
\hline $\mathrm{Tm}$ & 0.43 & 0.37 & 0.78 & 0.29 & 0.13 & 0.27 & 0.22 & 2.01 & 1.78 & 1.40 & 1.13 & 1.33 & 1.12 & 1.09 & 0.95 \\
\hline $\mathrm{Yb}$ & 2.69 & 2.45 & 4.79 & 1.89 & 0.80 & 1.65 & 1.42 & 11.92 & 10.70 & 8.19 & 6.83 & 7.97 & 6.80 & 6.60 & 5.78 \\
\hline Lu & 0.42 & 0.38 & 0.74 & 0.30 & 0.14 & 0.26 & 0.22 & 1.89 & 1.70 & 1.26 & 1.03 & 1.18 & 1.07 & 1.07 & 0.86 \\
\hline LREE & 200.4 & 129.9 & 403.5 & 90.6 & 25.2 & 72.9 & 71.0 & 1193.8 & 1281.5 & 944.7 & 814.0 & 852.6 & 1042.2 & 1427.3 & 573.9 \\
\hline HREE & 21.1 & 15.3 & 37.9 & 12.0 & 4.59 & 9.97 & 9.38 & 102.5 & 96.4 & 76.6 & 62.6 & 69.8 & 59.6 & 56.6 & 46.7 \\
\hline LREE/HREE & 9.50 & 8.48 & 10.7 & 7.54 & 5.49 & 7.31 & 7.57 & 11.7 & 13.3 & 12.3 & 13.0 & 12.2 & 17.5 & 25.2 & 12.3 \\
\hline REE & 221.5 & 145.3 & 441.3 & 102.6 & 29.8 & 82.8 & 80.4 & 1296.2 & 1377.9 & 1021.3 & 876.6 & 922.4 & 1101.8 & 1483.9 & 620.5 \\
\hline $\mathrm{Ce} / \mathrm{Ce}^{*}$ & 1.41 & 1.52 & 1.95 & 1.13 & 0.88 & 1.49 & 0.91 & 2.40 & 2.63 & 2.55 & 2.44 & 2.28 & 4.05 & 5.61 & 2.72 \\
\hline $\mathrm{Ce}_{\text {anomaly }}$ & 0.15 & 0.18 & 0.29 & 0.05 & -0.05 & 0.17 & -0.04 & 0.38 & 0.42 & 0.41 & 0.39 & 0.36 & 0.61 & 0.75 & 0.43 \\
\hline $\mathrm{Eu} / \mathrm{Eu}^{*}$ & 1.09 & 1.12 & 1.16 & 1.16 & 1.08 & 1.10 & 1.11 & 1.16 & 1.12 & 1.17 & 1.22 & 1.17 & 0.98 & 0.95 & 1.20 \\
\hline $\mathrm{Y}_{\mathrm{SN}} / \mathrm{Ho}_{\mathrm{SN}}$ & 0.83 & 0.86 & 0.75 & 1.01 & 1.40 & 1.25 & 0.92 & 0.59 & 0.61 & 0.59 & 0.60 & 0.63 & 0.67 & 0.80 & 1.15 \\
\hline
\end{tabular}

Calculated according Bau et al. (2014). 


\section{Discussion}

5.1. Province characteristics of Fe-Mn nodules and crusts on the seafloor

Fe-Mn nodules and crusts are found in a wide variety of oceanographic and tectonic settings. Accordingly, based on the formation environment, the northern SCS is divided into three Fe-Mn nodules provinces: the NESCS (Province A), NWSCS (Province B) and CBSCS (Province C, Fig. 1b). The most prominent physiographic features of the northern SCS are mud volcanoes and hydrocarbon seep structures located along the northeast margin (Chen et al., 2005), the Luzon Strait through which NPDW undercurrent circulates $(\mathrm{Qu}$ et al., 2006a), and widely distributed volcanic seamounts that formed after the cessation of seafloor spreading (Chung et al., 1997; Zhou et al., 2009). The field sites, morphology, mineralogical and geochemical data from this study and previous studies allow us to propose a comparison with other deep-seabed polymetallic nodules and shallow-water and continental margin nodules from other ocean basins and tectonic settings around the world. Moreover, based on these data we can discuss the different provincial characteristics of nodules and crusts growth in the oceanographic and geotectonic contexts of the northern SCS.

\subsubsection{Province A (NESCS)}

The nodule fields in Province A occur at the base of seepage mounds, where the influence of the NPDW is strong and where extensive hydrocarbon-rich fluid venting and mud diapirs are observed, which includes numerous mud volcanoes, methanerelated authigenic carbonates (crusts, chimneys), gas hydrates and pockmarks (Fig. 2a) (Han et al., 2013; Li et al., 2013b; Wang et al., 2014; Zhang et al., 2015). These geological and environmental conditions of Fe-Mn nodule fields on the NESCS are very similar to the occurrences in the Gulf of Cadiz (González et al., 2010, 2012).

The nodules physical properties such as maximum diameter, density, and weight are similar to nodules reported to occur in the shallow-waters and continental margins in the Baltic Sea, the Gulf of Finland, Black Sea and the Gulf of Cadiz (e.g., Hlawatsch et al., 2002; González et al., 2007; Zhamoida et al., 2007; Baturin, 2010). Rodlike, irregular and concretion morphologies are predom- inant in the Province A nodules (Table 1) as in other shallow water nodules such as those reported from the Gulf of Cadiz (González et al., 2007). Otherwise, cylindrical nodules are similar to the tabular concretions formed around burrows reported in the Black Sea (Baturin et al., 2002). The NESCS nodules are characterized by Fe oxyhydroxides (goethite type) predominating over Mn oxides unlike those in deep-sea nodules where Mn oxides are predominant (e.g., Hein et al., 2013). The silicates (clay minerals) present in the nodules are distinctive from the mud sediments with different sources than those of the hemipelagic samples. The abundance of clay minerals (especially smectite) are therefore characteristic of the nodules, and directly related to the fluid venting processes. Authigenic pyrite, barite and CFA in nodules reflect fluctuations in the redox boundaries probably associated with microbial cycles of metals in the seabottom sediments affected by hydrocarbon seeps (Vanneste et al., 2013).

Unlike oceanic polymetallic nodules (Chandnani et al., 2012; Hein et al., 2012; Wegorzewski and Kuhn, 2014), Province A samples plot in an area with high Fe content (13.0-45.5 wt.\%), low to moderate Mn content (0.03-12.4 wt.\%), and very low $\mathrm{Cu}+\mathrm{Co}+\mathrm{Ni}$ concentrations (0.01-0.76 wt.\%; Fig. 8, Table 3 and Supplement Table A3). The $\mathrm{Mn} / \mathrm{Fe}$ ratio is $0.002-0.95$, well below the $\mathrm{Mn} / \mathrm{Fe}$ ratio of typical oceanic polymetallic nodules. The PAASnormalized trace elements patterns show moderate enrichments in $\mathrm{Mo}, \mathrm{Pb}, \mathrm{Ba}, \mathrm{Co}, \mathrm{Ni}, \mathrm{V}$ and $\mathrm{Cr}$ (Fig. 9a). The total REE concentrations range from 29.8 to $441 \mu \mathrm{g} / \mathrm{g}$, with no and slight positive Ce anomalies $\left(\mathrm{Ce} / \mathrm{Ce}^{*}=0.88-1.51\right)$ and positive Eu anomalies $\left(\mathrm{Eu} / \mathrm{Eu}^{*}=1.08-\right.$ 1.16, Fig. 10a). All Fe-Mn nodule and crust layers have a small (1.11-1.29) positive shale-normalized Eu anomaly that most likely reflects that of seawater (Bau et al., 1996). However, for the Fe-rich nodules studied here, which likely formed subsurface, contained barite may also contribute to the positive Eu anomalies. In general, the REE contents of the NESCS Fe-Mn nodules are similar to modern seep carbonates in the Dongsha and Congo fans and hydrocarbon-derived Fe-Mn nodules and carbonate chimneys from the Gulf of Cadiz (Fig. 10d) (Feng et al., 2009; Ge et al., 2010; González et al., 2010; Magalhães et al., 2012). The REE in the most deep-ocean Fe-Mn deposits are hosted by the Fe and Mn phases and the total REE contents decrease with increasing diagenetic contributions (Hein and Koschinsky, 2013).
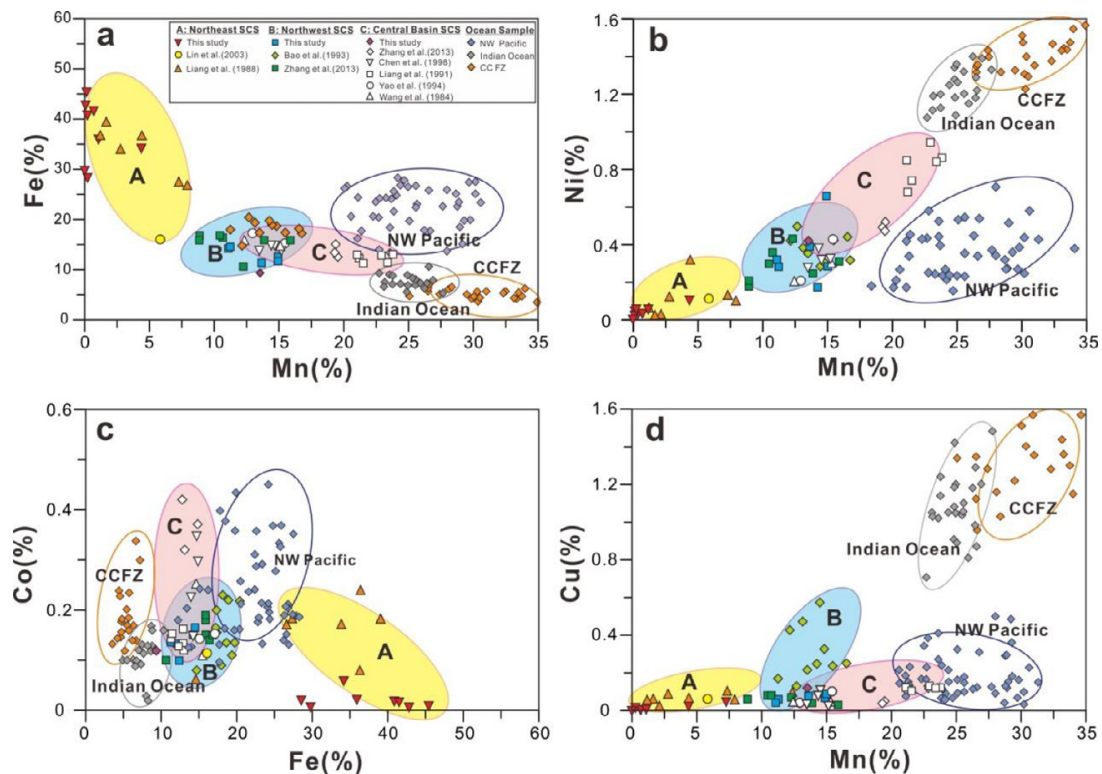

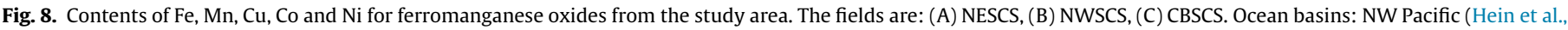
2012), Indian Ocean (Chandnani et al., 2012) and Clarion-Clipperton Fracture Zone (Wegorzewski and Kuhn, 2014). 
Table 3

Abundance (weight percent) of important elements in manganese nodules by province in the northern South China Sea.

\begin{tabular}{|c|c|c|c|c|c|c|c|c|c|}
\hline \multicolumn{2}{|c|}{ Physiographic Province } & \multirow{2}{*}{$\frac{\mathrm{Ni}+\mathrm{Cu}+\mathrm{Co} \text { (wt.\%) }}{0.01}$} & \multirow{2}{*}{$\frac{\mathrm{Mn} / \mathrm{Fe}}{0.002}$} & \multirow{2}{*}{$\frac{\mathrm{Mn}}{0.033}$} & \multirow{2}{*}{$\frac{\mathrm{Fe}}{13.0}$} & \multirow{2}{*}{$\begin{array}{l}\text { Co } \\
0.002\end{array}$} & \multirow{2}{*}{$\begin{array}{l}\mathrm{Ni} \\
0.004\end{array}$} & \multirow{2}{*}{$\frac{\mathrm{Cu}}{0.0005}$} & \multirow{2}{*}{$\begin{array}{l}\Sigma \text { REE }(\mu \mathrm{g} / \mathrm{g}) \\
29.8\end{array}$} \\
\hline Province A & Min & & & & & & & & \\
\hline & Max & 0.76 & 1.08 & 12.4 & 45.5 & 0.24 & 0.56 & 0.09 & 441 \\
\hline & mean & 0.23 & 0.95 & 3.26 & 32.1 & 0.08 & 0.11 & 0.03 & 158 \\
\hline \multirow[t]{3}{*}{ Province B } & Min & 0.34 & 0.54 & 8.90 & 10.0 & 0.08 & 0.18 & 0.03 & 841 \\
\hline & Max & 2.96 & 1.67 & 17.0 & 20.4 & 0.23 & 0.86 & 2.48 & 2771 \\
\hline & mean & 0.79 & 0.90 & 13.4 & 15.7 & 0.15 & 0.38 & 0.26 & 1530 \\
\hline \multirow[t]{3}{*}{ Province $\mathrm{C}$} & Min & 0.35 & 0.75 & 12.4 & 9.4 & 0.11 & 0.20 & 0.03 & 620 \\
\hline & Max & 1.21 & 2.05 & 23.8 & 17.2 & 0.42 & 0.94 & 0.13 & 1524 \\
\hline & mean & 0.81 & 1.35 & 17.8 & 13.6 & 0.21 & 0.52 & 0.08 & 1203 \\
\hline
\end{tabular}

Min = minimum; Max $=$ maximum
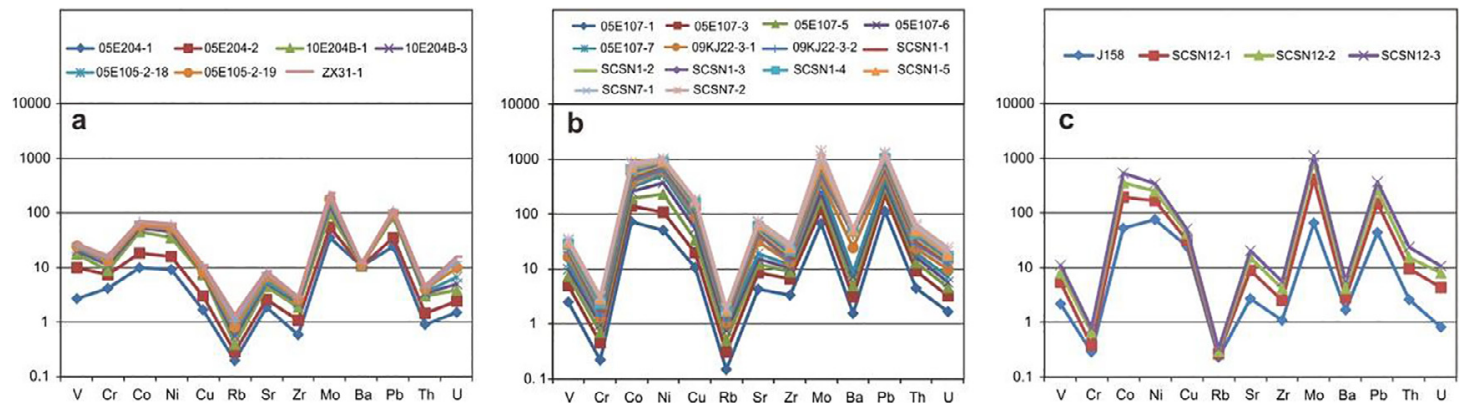

Fig. 9. PAAS-normalized trace element patterns of (a) NESCS (Province A); (b) NWSCS (Province B) and (c) CBSCS (Province C) samples in the northern SCS.
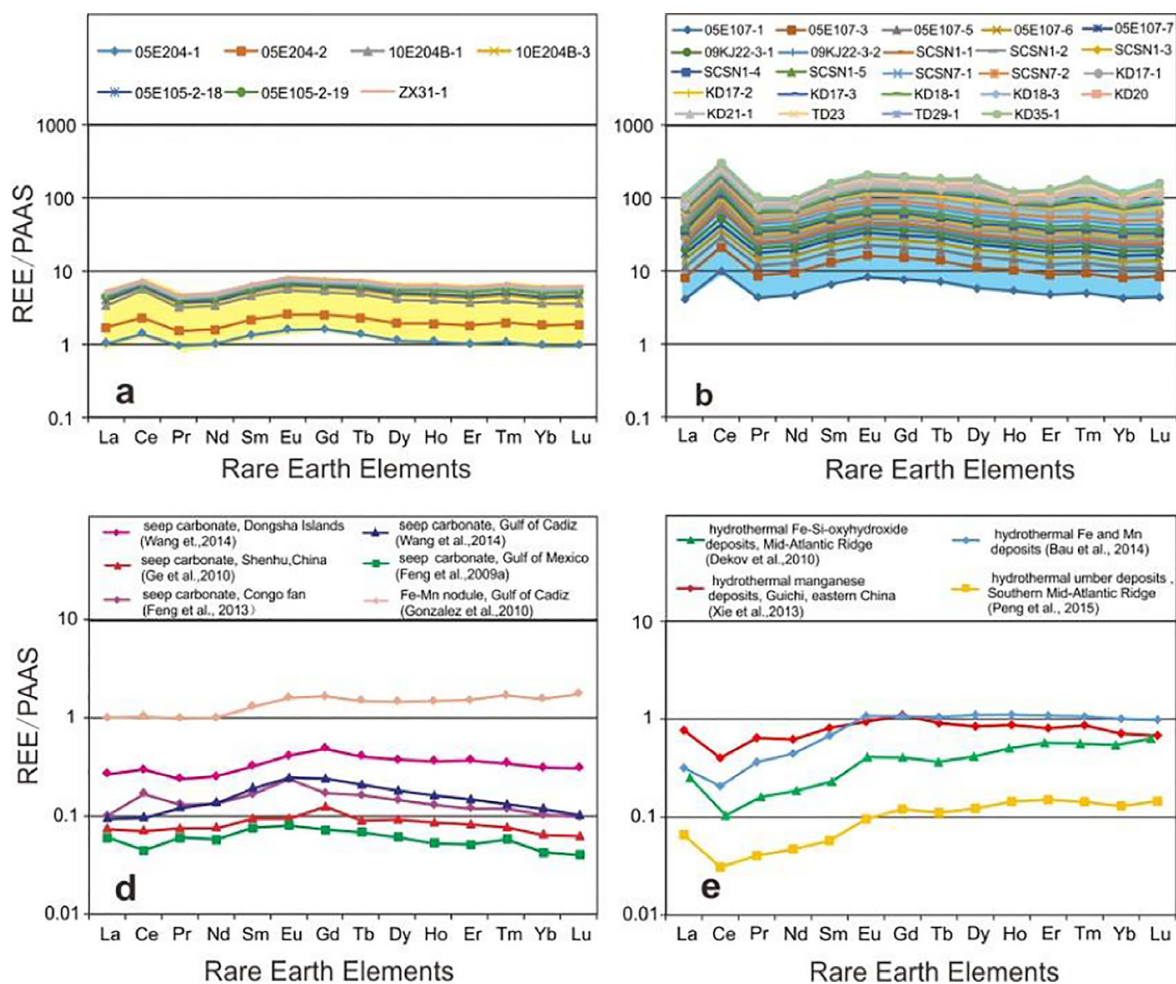

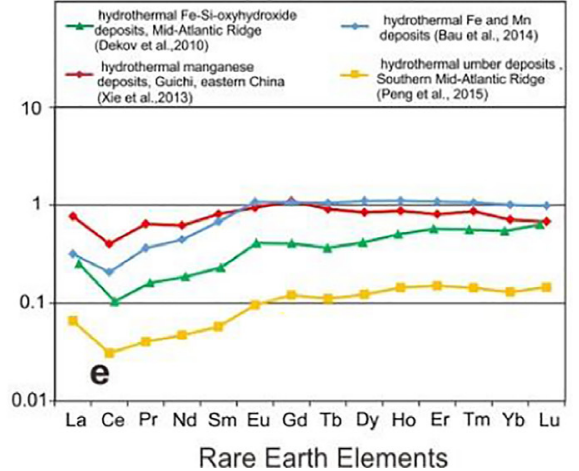

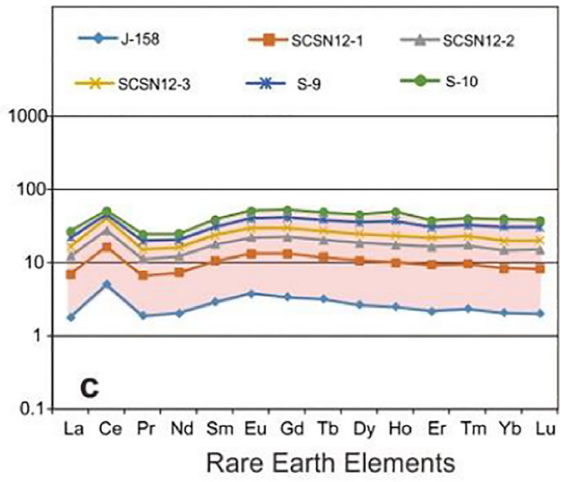

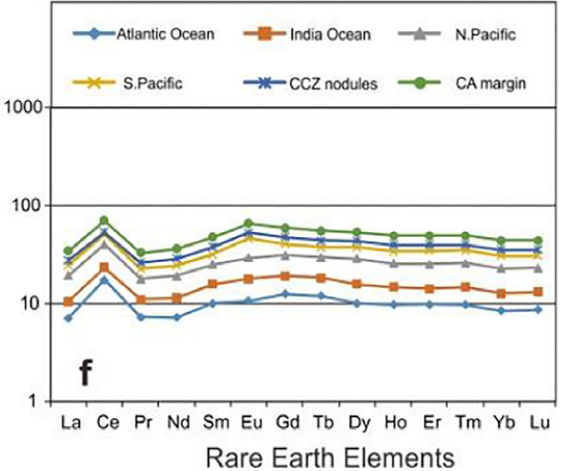

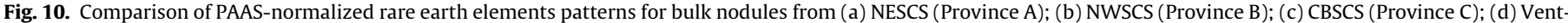
related precipitates and fluids; (e) Hydrothermal hydroxides; (f) From elsewhere (Hein et al. (2000) and Hein and Koschinsky (2013)).

\subsubsection{Province $B$ (NWSCS)}

The nodule and crust fields are distributed on the northern slope of the SCS where the NPDW influence is stronger than in Province A and C. The deep water $(>2000 \mathrm{~m})$ currents of the SCS which are strongest along the SCS slope (Lüdmann et al., 2005; Shao et al., 2007; Gong et al., 2012), promote nodules and crusts formation, enhance turbulent mixing, and produce upwelling, leading to increased primary productivity and the maintenance of an oxygen minimum zone (Hein et al., 2010).

Province B covers a broad area, including extensive areas of $\mathrm{Fe}$ Mn nodules and sporadic crusts. Spherical, tabular to irregular morphologies predominant in the northern slope are similar to 
nodules reported to occur in the Pacific (Hein et al., 2012) and Indian Ocean basins (Pattan and Parthiban, 2011; Pattan et al., 2013). The scattered Fe-Mn crusts are mostly distributed around Zhongsha and Xisha carbonate platforms. Previous studies of hydrogenetic nodules show strong similarities with hydrogenetic Fe-Mn crusts in the NWSCS with respect to both mineralogical and chemical compositions, reflecting largely identical mechanisms of formation (Bao and Li, 1993). Nodules and crusts from Province $\mathrm{B}$ are characterized by moderate $\mathrm{Fe}$ and $\mathrm{Mn}$ contents ( $\sim 9-20$ wt.\%) and are more enriched in $\mathrm{Cu}, \mathrm{Co}$ and Ni (Table 3 and Supplement Table A3) than Province A samples. The chemical composition of the Province B Fe-Mn nodules is different from the Indian Ocean (Mukhopadhyay et al., 2003) and CCFZ nodules (Wegorzewski and Kuhn, 2014), but relatively close to the northwest Pacific nodules (Hein et al., 2012) (Fig. 8). The PAASnormalized trace elements patterns of NWSCS nodules are strongly enriched in $\mathrm{Mo}, \mathrm{Pb}, \mathrm{Co}, \mathrm{Ni}$ and $\mathrm{Cu}$ and moderately depleted in $\mathrm{V}, \mathrm{Rb}$ and $\mathrm{Cr}$ (Fig. 9b). The total REE concentrations range from 841 to $2771 \mu \mathrm{g} / \mathrm{g}$ (Table 3 and Supplement Table A3), with positive Ce $\left(\mathrm{Ce} / \mathrm{Ce}^{*}=2.06-5.61\right)$ and $\mathrm{Eu}\left(\mathrm{Eu} / \mathrm{Eu}^{*}=0.89-1.48\right)$ anomalies (Fig. 10b). Marine authigenic Fe-Mn oxyhydroxides of hydrogenetic origin commonly show positive Ce anomalies owing to the oxidation of $\mathrm{Ce}^{3+}$ to $\mathrm{Ce}^{4+}$ in seawater and its subsequent uptake as $\mathrm{CeO}_{2}$ by metalliferous nodules or crusts (Piper, 1974; Nath et al., 1992). As with the NESCS samples, the NWSCS nodules with a positive Eu anomaly most likely reflects that of seawater and contained barite. The enrichment of trace metals of economic interest in Fe-Mn nodules and crusts is particular important for their potential as a strategic resource, because of the high concentrations of REE (Fig. 10). CFA that forms phosphorites also hosts REE in a wide variety of environments along continental shelves and slopes of Pacific and Atlantic oceans (Hucrrns et al., 1991; Hughes and Rakovan, 2015). CFA concentrates REE during its formation through early diagenetic processes. However, these continental-margin phosphorites typically have lower total REE contents than do Fe-Mn nodules (Hein et al., 2016). Mass-balance considerations indicate that most of REE are hosted by the oxide phases rather that the apatite minerals found in these NWSCS and NESCS nodules. In support of this, the correlation coefficients show no correlations between REEs and $\mathrm{P}$ (Supplementary Table A2).

\subsubsection{Province $C(C B S C S)$}

The largest region for manganese accumulations in the northern SCS is a broad belt of deposits in the central basin, where bottom roughness is highly variable. Nodule and crust deposits appear to be concentrated between $\sim 1000 \mathrm{~m}$ and $>3000 \mathrm{~m}$ water depths and are particularly abundant in the deepest parts of the central basin, extending into the Zhongnan faults zone between about 14 and $16^{\circ} \mathrm{N}$. The Province $\mathrm{C}$ deposits are mostly Fe-Mn crusts widely distributed on the volcanic seamounts that formed after the cessation of the seafloor spreading in the basin (Fig. 1; Yao, 1996), such as Daimao Seamount (8\# station), Xianbei Seamount (Xianbei station), and Zhenbei Seamount (9\# station). Chemical and mineralogical composition of the Fe-Mn nodules and crusts indicate that they have similar geochemical characteristics and occasionally occur together in the same area (e.g., Site 10\#, Fig. 1b, Table 1). Most known major seamounts are along, or to the north of, the relict spreading center in the southwest sub-basin (Fig. 2b) and are composed mainly of alkali basalts with subordinate tholeiites that display oceanic island basalt-type geochemical characteristics (Xu et al., 2012). These seamounts and ridges have characteristics that promote development of Fe-Mn crusts and the adsorption of metals from cold seawater, with possible contributions from submarine volcanism/hydrothermal venting.
All the Fe-Mn nodules and crusts are composed predominantly of todorokite and X-ray amorphous iron oxyhydroxide. Mn contents of CBSCS Fe-Mn nodules and crusts vary widely (12.423.8 wt.\%) with total $\mathrm{Cu}, \mathrm{Ni}$ and $\mathrm{Co}$ concentrations of $0.35-$ 1.21 wt.\%, which are close to the range for Province B deposits, Indian Ocean nodules (Mukhopadhyay et al., 2003), and the northwest Pacific Ocean nodules (Hein et al., 2012) (Fig. 8, Table 3 and Supplement Table A3). The PAAS-normalized trace elements patterns show enrichment in $\mathrm{Mo}, \mathrm{Co}, \mathrm{Ni}, \mathrm{Cu}$, and moderate to strong depletion in $\mathrm{V}, \mathrm{Cr}$ and $\mathrm{Rb}$ (Fig. 9c). The total REE concentrations range from 620.6 to $1524.1 \mu \mathrm{g} / \mathrm{g}$, with positive Ce anomalies (Ce/ $\left.\mathrm{Ce}^{*}=2.28-3.14\right)$ and $\mathrm{Eu}\left(\mathrm{Eu} / \mathrm{Eu}^{*}=1.01-1.20\right)$ anomalies (Fig. 10c), which are similar to oceanic hydrogenetic nodules and crusts (Fig. 10f; Bau et al., 1996; Hein and Koschinsky, 2013).

\subsection{Proposed genetic model of the Fe-Mn nodules and crusts}

Numerous authors have described Fe-Mn concretions associated with a contourite depositional system (CDS) in relation to their typology (nodules, micronodules, laminations and crusts) or their geological and oceanographic context (e.g., Stow et al., 2002). However, few reported references link the geochemistry of Fe-Mn concretions and a CDS (González et al., 2012). Contour currents and their deposits are related to continental margins in all of the ocean basins. The CDS often coincides with areas affected by deep-seated fluid venting (mud volcanism and diapirism), as occurs in the Gulf of Cadiz, Brazil Basin, Gulf of Mexico, Argentine Atlantic margin, Alboran Sea and SCS (Diáz-del-Rio et al., 2003; Chen et al., 2005; Hernández-Molina et al., 2006, 2010; González et al., 2007; Magalhães et al., 2012; Somoza et al., 2012). Furthermore, the SCS is also affected by different structures and deposits related to fluid venting and their hydrocarbon-derived carbonates and authigenic barite deposits (Torres et al., 2003; Vanneste et al., 2013; Han et al., 2014; Feng and Chen, 2015). Previous studies showed that Fe-Mn nodules in the SCS were mainly hydrogenetic deposits (Lin et al., 2003). However, little work on genetic models for nodule and crust growth in the different oceanographic and geotectonic settings in this area has been undertaken.

Based on mineralogy, composition, source of fluids and tectonic settings, sedimentary Fe-Mn oxides are classified as hydrogenetic, diagenetic, hydrothermal and mixed-type deposits (Bolton et al., 1988; Hein et al., 1997). Traditionally, the genesis of oceanic nodules and crusts can be discriminated by using the ternary diagram $\mathrm{Mn}-\mathrm{Fe}-(\mathrm{Cu}+\mathrm{Ni}+\mathrm{Co}) \times 10$ (Bonatti et al., 1972). Mn/Fe ratios for other deep-sea polymetallic nodules are different compared to shallow water continental margin nodules from other ocean basins and nodules and crusts from the northern SCS from this and previous studies (Fig. 11 and Supplement Table A3). However, this approach cannot be used to clearly distinguish between hydrothermal and diagenetic precipitates. The REY pattern can be used to differentiate between hydrothermal $\mathrm{Mn}$ and Fe deposits, diagenetic Fe-Mn nodules, and hydrogenetic Fe-Mn nodules and crusts (Bau et al., 2014).

Compared with typical oceanic hydrogenetic-diagenetic nodules from the Indian Ocean (Mukhopadhyay et al., 2003) and CCFZ (Wegorzewski and Kuhn, 2014), most of the nodules and crusts from the northern SCS plot in the hydrogenetic or mixed hydrogenetic-hydrothermal fields on this ternary diagram (Fig. 11). The NESCS Fe-rich nodules contain redox-sensitive minerals (such as pyrite) (Fig. 6a), reflecting mineralization fronts associated with redox boundaries in the sediment column during early diagenesis, as also occur in Fe-Mn nodules from the Gulf of Cadiz (González et al., 2012). Furthermore, most NESCS nodules exhibit $\mathrm{Mn} / \mathrm{Fe}$ values $<0.25$ and low contents of $\mathrm{Co}, \mathrm{Ni}, \mathrm{Cu}$ and REEs (Table 2), and plot near the Fe end member (Fig. 11a). There are many studies documenting nodules from shallow waters and con- 

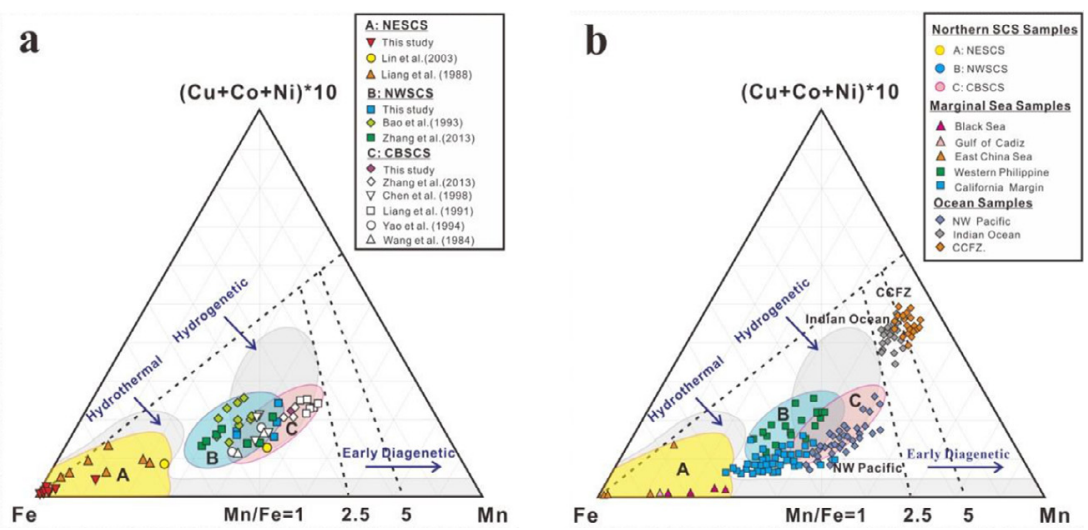

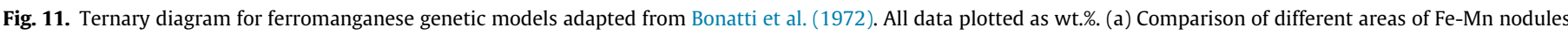

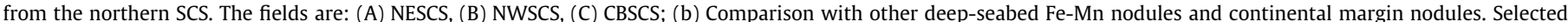

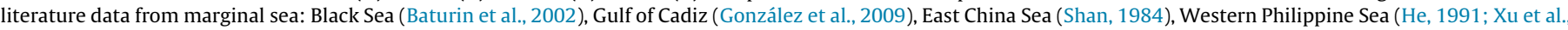

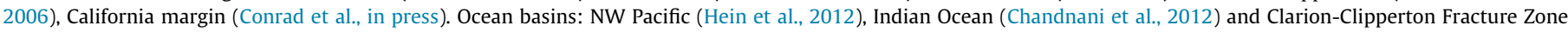
(CCFZ) (Wegorzewski and Kuhn, 2014).

tinental margins where Fe, Mn and trace metal contents are similar to the nodules from the NESCS (Glasby et al., 1997; Baturin et al., 2002; González et al., 2009). All of those deposits display very low $\mathrm{Mn} / \mathrm{Fe}$ ratios as a result of growth by predominantly diagenetic processes. In addition, the content of some elements in the nodules from the NESCS ( $\mathrm{V}, \mathrm{Ca}, \mathrm{Mg}, \mathrm{Ni}, \mathrm{Co}, \mathrm{Mo}$ ) are more similar to shallowwater nodules from the Black Sea (Baturin et al., 2002), Gulf of Cadiz (González et al., 2007) and East China Sea (Shan, 1984) than to deep-sea nodules (Hein and Koschinsky, 2013). Co concentrations (up to 0.06 wt.\%) and a slight positive Ce anomaly in some nodules from the NESCS (Fig. 10a) indicate exposure to bottom waters and hydrogenetic growth. The continental-margin-type nodules show lower total $\mathrm{Co}+\mathrm{Cu}+\mathrm{Ni}$ content and higher $\mathrm{Fe}, \mathrm{Al}$, and $\mathrm{Cr}$ concentrations than open-ocean nodules, reflecting the higher terrigenous input per unit area into the SCS (Koschinsky and Halbach, 1995; Hein et al., 2010).
On bivariate diagram of $\mathrm{Ce}_{\mathrm{SN}} / \mathrm{Ce}_{\mathrm{SN}}^{*}$ versus $\mathrm{Nd}$ concentration (Fig. 12a), the Fe-rich nodules lack $\mathrm{Ce}$ anomalies and Nd concentrations are low $(5-60 \mu \mathrm{g} / \mathrm{g})$. In the bivariate diagram of $\mathrm{Ce}_{\mathrm{SN}} / \mathrm{Ce}_{\mathrm{SN}}^{*}$ versus $\mathrm{Y}_{\mathrm{SN}} / \mathrm{Ho}_{\mathrm{SN}}$ ratio (Fig. 12b), the Fe-rich nodules show slight negative $\mathrm{Y}$ and $\mathrm{Ce}$ anomalies. Both diagrams discriminate these nodules as diagenetic in origin, but overlaps slightly with the hydrothermal field. Negative Ce anomalies have also been found in a number of hydrothermal Fe-Si-oxyhydroxides (Fig. 10e) and have precipitated from a fluid composed primarily of ambient seawater with little hydrothermal fluid (Dekov et al., 2007). Alternatively, negative $\mathrm{Ce}$ anomalies in seep carbonates suggest that they may result from high porewater alkalinity in the presence of organic matter (Fig. 10d). In addition, the average GR of the NESCS nodules $(3320 \mathrm{~mm} / \mathrm{Myr})$ is slower than those calculated for shallow-water Baltic Sea nodules (average rate is $20,000 \mathrm{~mm} /$ Myr) (Zhamoida et al., 1996; Hlawatsch et al., 2002), but several
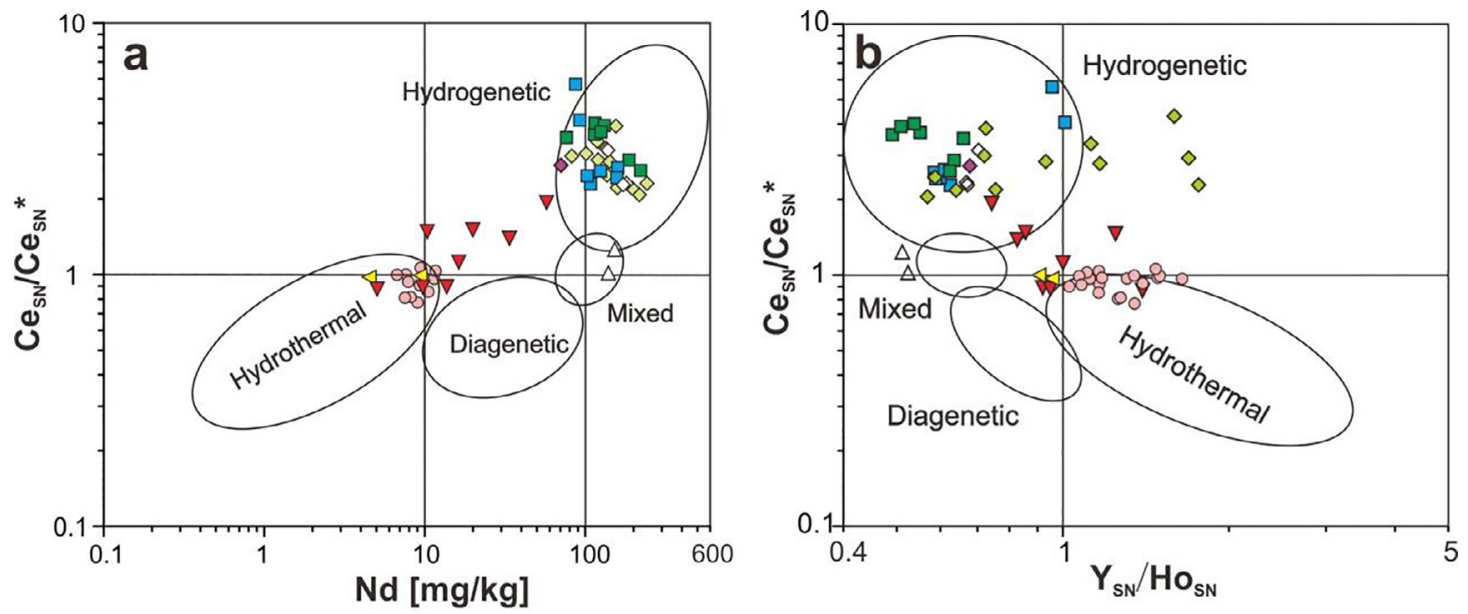

\begin{tabular}{|lll|}
\hline A: NESCS & B: NWSCS & C: CBSCS \\
$\nabla$ This study & $\square$ This study & $\diamond$ This study \\
$\triangleleft \begin{array}{l}\text { Galicia Bank } \\
\text { (Gonzalez et al.,2016) }\end{array}$ & $\diamond$ Bao et al.(1993) & $\diamond$ Zhang et al.(2013) \\
$\begin{array}{l}\text { Gulf of Cadiz } \\
\text { (Gonzalez et al., 2012) }\end{array}$ & $\square$ Zhang et al.(2013) & $\triangle$ Wang et al. (1984) \\
\hline
\end{tabular}

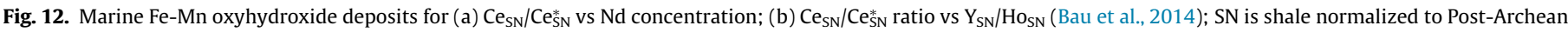
Australian Shale, PAAS (McLennan, 1989). 
orders of magnitude higher than GRs of hydrogenetic NWSCS and CBSCS nodules (from 4 to $7 \mathrm{~mm} / \mathrm{Myr}$ ). Therefore, fast growth rates emphasize the importance of sediment diagenetic processes (Reyss et al., 1982). Furthermore, this relatively rapid accretion in a short span time is probably one of the main causes for the overall low content of transition metals other than Fe and REE in these continental margin nodules.

The Fe-Mn nodule samples in the NWSCS result in $\mathrm{Mn} / \mathrm{Fe}$ values between 0.54 and 1.25 with a mean of 0.89 , which is consistent with a predominantly hydrogenetic origin for these continentalmargin Fe-Mn nodules and crusts. They are similar to other samples from the western Philippine Sea (He, 1991; Xu et al., 2006) and, California continental-margin (Conrad et al., in press), and are more enriched in Fe than the crusts from the Pacific Ocean (Hein et al., 2012). In addition, these nodules show high contents of Ti and REE and strong positive Ce anomalies, characteristic of a hydrogenetic origin. Most samples plot outside of the typical open-ocean hydrogenetic field, but within the field typical for Pacific continental-margin and small ocean basin Fe-Mn crusts (Hein et al., 2000). Data that plot in the transition between the diagenetic and hydrogenetic end members indicate participation by both processes in nodule formation (Fig. 11b). Fe-Mn nodules and crusts from the CBSCS plot in and near the typical open-ocean hydrogenetic field and are similar to deep-sea nodules from the northwest Pacific (Hein et al., 2012) (Fig. 11b). Nodule J-158 from the CBSCS contains relatively low $\mathrm{Co}(0.12 \mathrm{wt} . \%)$ and high $\mathrm{Cu}$ and $\mathrm{Ni}$, probably indicating a predominance of diagenetically produced metals, with less hydrogenetic input. Plots of the NWSCS and CBSCS Fe-Mn nodules and crusts REY data normalized to PAAS are consistent with typical hydrogenetic Fe-Mn crusts plots (McLennan, 1989; Bau et al., 2014) (Fig. 12). This characteristic hydrogenetic pattern shows a large positive Ce and negative $\mathrm{Y}$ anomalies, with some samples showing smaller positive anomalies for $\mathrm{Eu}, \mathrm{La}$, and $\mathrm{Gd}$ (Bau et al., 1996). Patterns from NWSCS and CBSCS Fe-Mn nodules and crusts samples show REY data generally consistent with hydrogenetic Fe-Mn crust patterns; two samples from stations S9 and S-10 show less REY enrichment relative to PAAS, similar to mixed origin Fe-Mn nodules. Those crusts, might have had a diagenetic input from redox cycling in sediment from a nearby seamount.

\subsection{Metal sources for Fe-Mn nodule and crust formation}

The field sites, morphological characteristics, mineralogical and geochemical data from this study were compared with other deep seafloor Fe-Mn nodules and crusts, and shallow-water and continental-margin nodules from other ocean basins and tectonic settings. The substrate materials for northern SCS nodules and crusts are complex and include consolidated sediment (silicates, siliceous clay, silty clay and siliceous soft mud) (Luo et al., 1994) and basalt (Yan et al., 2015). There has also been controversy about the metal sources for the Fe-Mn nodules and crusts, with proposed sources including terrestrial weathering, submarine volcanic activity and seawater (Wang et al., 1986; Bao and Li, 1993; Lin et al., 2003).

To better understand the different genetic processes and metal sources for the northern SCS nodules and crusts, analytical data of Fe-Mn nodules and crusts from 28 different locations are used in a comparative study of latitudinal and longitudinal control on geochemical variation of samples (Supplement Table A3, Fig. 13). Ear-
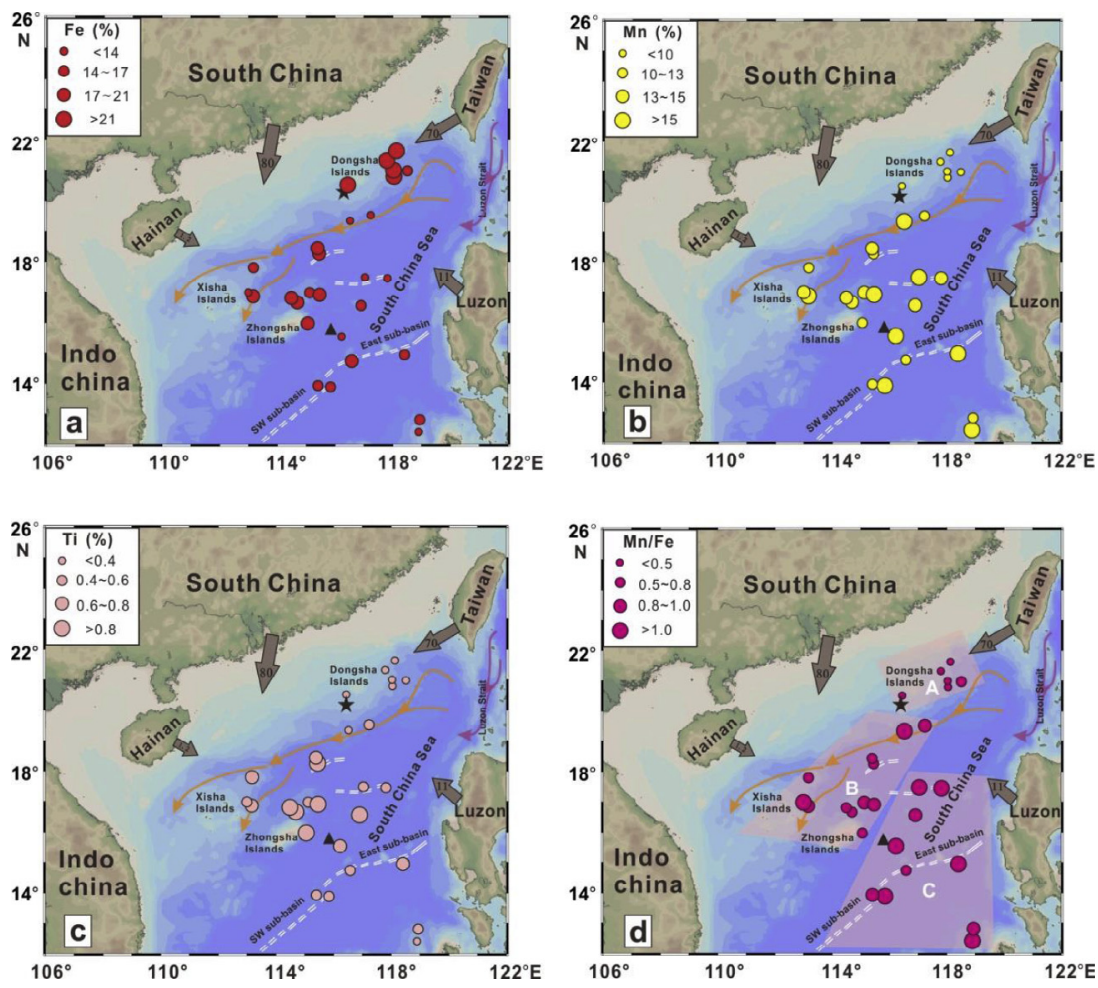

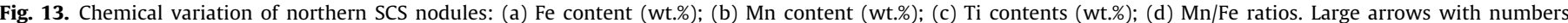

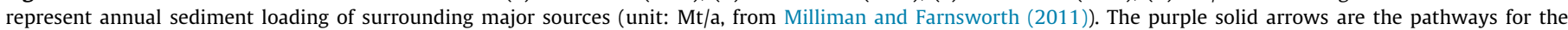

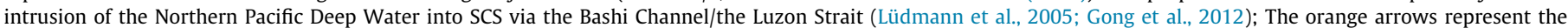

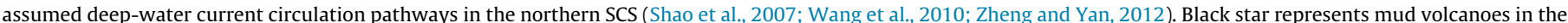

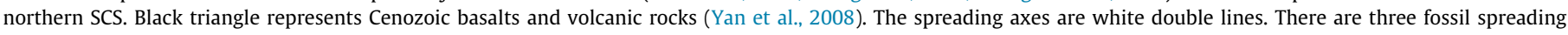

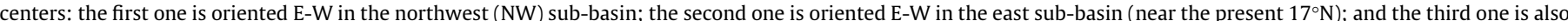

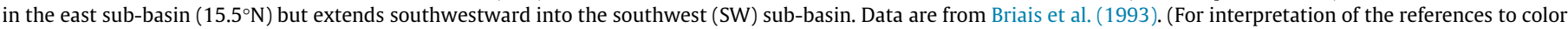
in this figure legend, the reader is referred to the web version of this article.) 
lier studies reported higher concentrations of $\mathrm{Mn}, \mathrm{Ni}$ and $\mathrm{Cu}$ in nodules from siliceous sediments from the Central Indian Ocean Basin, indicating the influence of early diagenesis of organic matter in the sediments. In contrast, higher Fe and Co contents in nodules from pelagic red clay deposits are a result of greater hydrogenetic precipitation (Rao, 1987; Jauhari, 1989; Sudhakar, 1989). In the Marmara Basin of the Black Sea, high Mn concentrations are related to volcanic activity along fault planes (Ergin, 1994). Manganese is influenced by these processes and reduced Mn is remobilized from diagenetic reactions in shelf sediments. Unlike Fe, $\mathrm{Mn}$ in northern SCS nodules and crusts does not show a concentration increase towards the continental shelf. Manganese does show a negative correlation with increasing water depth as expected since dissolved Mn is enriched in seawater in the OMZ. Mn concentrations in Fe-Mn crusts are controlled by the redox potential of seawater from which the crusts formed. In the CBSCS, Mn/Fe values vary from 0.95 to 2.04 , reflecting their open-ocean-type hydrogenesis, with possibly a minor diagenetic input (Fig. 13d). The todorokite and birnessite present in CBSCS nodules could be interpreted to indicate a suboxic diagenetic input and for crusts suboxic bottom water conditions. It is more likely that lower oxidation potential seawater conditions under which CBSCS deposits formed allowed for the precipitation of these Mn minerals that are less oxic than $\delta-\mathrm{MnO}_{2}$, the mineral that typifies open-ocean crusts (Conrad et al., in press).

Moreover, along $18^{\circ} \mathrm{N}$, Fe-Mn nodules and crusts show higher Mn concentrations and higher $\mathrm{Mn} / \mathrm{Fe}$ compared with the NESCS, where the Fe content is highest. The chemistry of CBSCS nodules and crusts from the central deep basins located between the seamount chains is probably related to major fracture zones (e.g., Zhongnan Faults Zone) (Figs. 2b and 13b and d). Most of these seamounts in Province $C$ are thought to have been emplaced after seafloor spreading stopped about $15 \mathrm{Ma}$ ago. $\mathrm{K}-\mathrm{Ar}$ and ${ }^{40} \mathrm{Ar}-{ }^{39} \mathrm{Ar}$ ages of dredged samples from seamounts as well as volcaniclastic records are all younger than $15 \mathrm{Ma}$ (Wang et al., 1985; Kudrass et al., 1986; Yan et al., 2008), the estimated cessation age of seafloor spreading in the SCS. Especially, the Sc concentration in FeMn nodules ( $\mathrm{Sc}=13 \mu \mathrm{g} / \mathrm{g}$ ) and volcaniclastic rocks $(\mathrm{Sc}=20 \mu \mathrm{g} / \mathrm{g}$; Yan et al., 2008) in the CBSCS are similar and higher than that I the slope area $(\mathrm{Sc}=9.7 \mu \mathrm{g} / \mathrm{g})$. Sc is enriched in upper mantle and lower continental crust rocks, which suggests that the detrital fraction of the Fe-Mn nodules and crusts derives from the seafloor sediment and volcanic material (Ma et al., 1987). However, based on mass balance considerations, most of the Sc in the nodules must be sorbed, most likely on the Fe oxyhydroxide (Koschinsky and Hein, 2003). Similarly, the high Li content $(64 \mu \mathrm{g} / \mathrm{g})$ observed in nodule J-158 and moderate-to-high $\mathrm{Mo}, \mathrm{V}$ and $\mathrm{Pb}$ concentrations could be related to volcanic-hydrothermal activity (Chan and Hein, 2007). Alternatively, the high Li contents in nodules are commonly of diagenetic origin, derived for redox reactions in the sediment (Hein and Koschinsky, 2013). As a result, these nodules and crusts act as a sink for metals dissolved in seawater in the CBSCS from the late Cenozoic to the present.

The NWSCS supports mostly smooth Fe-Mn nodules, which are essentially hydrogenetic with minor diagenetic input, and likely affected by a CDS. Terrestrial sources deliver trace metals to the surface ocean, specifically fluvial particulate matter delivered during winter precipitation is a significant source of $\mathrm{Fe}, \mathrm{Mn}$ and other trace metals to the continental shelf (Liu et al., 2008). Eolian sources also contribute to the trace metal budget of the surface ocean (Chung et al., 2004). The strong positive Ce anomalies and high Ti (up to 1.57 wt.\%) and Co (up to 0.23 wt.\%) contents reflect water-mass dissolved metal composition and terrigenous input. Most of these nodules are located from 1000 to $2500 \mathrm{~m}$ water depth within or just below the oxygen minimum zone that promotes the enrichment in Mn, P, Co and other metals. Furthermore,
Ba and $P$ both have nutrient-type profiles in seawater and can be used as a tracer of primary productivity (Chan et al., 1976; Broecker et al., 1982; Paytan and Griffith, 2007). They are also enriched in the NWSCS Fe-Mn nodules and crusts relative to open-ocean crusts. With the exception of a few outliers, P shows higher concentrations in near shore Fe-Mn deposits relative to off shore samples, which probably reflects the strong upwelling and primary productivity.

The SCS continental margin, especially in the NESCS, should promote the mobilization of Fe through redox reactions in the sediment and transport of dissolved Fe to the deeper areas (Conrad et al., in press; Fig. 13a), as in the Gulf of Cadiz (González et al., 2012). Fe-Mn oxide nodules from the Gulf of Cadiz have been described to occur in carbonate mud mounds related to fluid venting and also suggested to be strongly influenced by the Mediterranean Outflow Water (González et al., 2007). But in the NESCS, seepage activity gives rise to a variety of seafloor features including mud volcanoes and diapirs, pockmarks, brine pools and authigenic deposits of carbonates and barite (Figs. 2 and 13) (Chen et al., 2005; Han et al., 2014; Feng et al., 2015). This indicates that there is hydrocarbon-rich fluid flow originating at depth in the sediments in the NESCS, similar to the Gulf of Cadiz (Somoza et al., 2003; González et al., 2009; Medialdea et al., 2009). The genesis of Cadiz Gulf nodules and the NESCS Fe-rich nodules, originally composed of authigenic barite-pyrite and some pyrite-phosphate concretions, are associated with methane seeps that can aid in understanding fluid flow and sedimentary redox processes. The main source of Ba for the formation of authigenic barite in marine sediments is generally considered to be the dissolution of biogenic barite in sulphate-depleted porewaters (Brumsack, 1989; Torres et al., 1996). In this way, the precipitation of pyrite occurs by microbially produced $\mathrm{HS}^{-}$reaction with iron from the sediments. Barite precipitation, on the other hand, takes place within the sediments through mixing of barium-rich, reduced seep fluids with pore water containing sulphate ion that is residual from microbial reduction in a semi-closed system (Canet et al., 2013). Furthermore, the lowest $\mathrm{Mn} / \mathrm{Fe}$ and Ti concentrations are found for small Fe-rich nodules, suggesting formation within suboxic sediment during early diagenesis or on the seabed with minor hydrogenetic input (Fig. 13d). Ti is acquired primarily through sorption onto the Fe oxyhydroxide (Koschinsky and Hein, 2003), so its low concentration is related to the rapid growth of the nodules, which did not allow time for significant sorption to occur. This hydrocarbon flow promoted fluid migration (methane and metallic ions) and complexes with the metal ions in the sediment, together commonly through sulphate-reducing bacteria mediation (González et al., 2012).

\section{Conclusions}

In this paper, by combining new data and previous data for the northern SCS, we synthesize the mineralogical-geochemical data of Fe-Mn deposits over the entire northern SCS. The mineral deposits include three types: (1) Fe-rich nodules containing essentially goethite from the NESCS, with $\mathrm{Mn} / \mathrm{Fe}<0.25$, low contents of $\mathrm{Co}$, $\mathrm{Ni}, \mathrm{Cu}$ in all samples, and very high estimated growth rates (up to $17,000 \mathrm{~mm} / \mathrm{Myr}$ ) indicating that diagenetic processes are predominant. The diagenetic processes are related to the deepseated hydrocarbon production and circulation resulting in seafloor seeps probably partially through microbially-mediated anaerobic oxidation, similar to the Gulf of Cadiz; (2) Smooth Fe-Mn nodules and crusts essentially composed of asbolane, todorokite and CFA in the NWSCS have similar Fe and Mn contents (Mn/ $\mathrm{Fe}=1.19)$ and moderate trace metal enrichments, which is consistent with a predominantly hydrogenetic origin of continental mar- 
gin Fe-Mn crusts; (3) Fe-Mn nodules and crusts composed of todorokite, asbolane, and birnessite in the CBSCS with higher Mn and lower Fe contents $(\mathrm{Mn} / \mathrm{Fe}=1.42)$ than NESCS and NWSCS samples, which plot in the typical open-ocean hydrogenetic field on discrimination diagrams.

A number of factors may have influenced the formation of $\mathrm{Fe}$ Mn nodules and crusts, especially their close proximity to terrestrial sources of dissolve and particulate material transported to the ocean, remobilization of Fe and $\mathrm{Mn}$ from sediment on the continental shelf and slope, upwelling and high primary productivity for high contents of $\mathrm{Ba}$ and $\mathrm{P}$ observed in nodules and crusts, and deep-water masses along the continental margin enriched in elements with long residence time. The concentration and distribution of $\mathrm{Fe}, \mathrm{Mn}, \mathrm{Ti}$ and $\mathrm{Mn} / \mathrm{Fe}$ in nodules and crusts from the northern SCS show geographic variation. The NESCS shows the lowest $\mathrm{Mn} / \mathrm{Fe}$ where small Fe-rich nodules occur, probably indicating a combination of early diagenetic, probably subsurface, formation with minor hydrogenetic input. They are derived from the oxidation of pyrite and pyrite-barite concretions, which are in related with redox boundaries and the methane-sulphate transition zone in the sediment. Iron is higher in NWSCS Fe-Mn nodules and crusts than in those from the open ocean, resulting in a higher $\mathrm{Fe} / \mathrm{Mn}$ ratio. The Fe enrichment is due to redox cycling in continental shelf and slope sediment. The NWSCS deposits show increasing Fe concentrations with proximity to the continental shelf. The Ba and $\mathrm{P}$ are the elements associated with primary productivity and are enriched in the NWSCS deposits. The NWSCS supports mostly Fe-Mn smooth nodules that are essentially hydrogenetic with possibly a minor diagenetic input, and were likely affected by a CDS. However, CBSCS nodules and crusts from the central deep basins located between the seamount chains, enriched in Sc and $\mathrm{Li}$, are hydrogenetic and spatially related to the major fracture zone and associated volcanic-hydrothermal activity.

\section{Acknowledgements}

We are grateful to Prof. Dong Feng for their guidance and constructive discussions and Xuebo Yin, Yao Guan for help with element and petrology analyses. We thank Editor-in-Chief Mei-Fu Zhou, Dr. J.N. Pattan and other anonymous reviewers for their suggestions that improved the manuscript. This work has been financially supported by the project of the Chinese National Science Foundation (contracts 41376057, 41676056, 41306047) and the Spanish project SUBVENT (CGL2012-39524-C02). This study was benefited from the scientific cooperation between the South China Sea Institute of Oceanology and the Geological Survey of Spain (IGME).

\section{References}

Aplin, A.C., Cronan, D.S., 1985. Ferromanganese oxide deposits from the Central Pacific Ocean, II. Nodules and associated sediments. Geochim. Cosmochim. Acta $49,437-451$

Bao, G.D., Li, Q.X., 1993. Geochemistry of rare earth elements in ferromanganese nodule (crusts) of the South China Sea. Oceanol. Limnol. Sin. 24, 304-313 (in Chinese with English abstract).

Barckhausen, U., Engels, M., Franke, D., Ladage, S., Pubellier, M., 2014. Evolution of the South China Sea: revised ages for breakup and seafloor spreading. Mar. Petrol. Geol. 58, 599-611.

Baturin, G., 1988. Manganese in Pore Water of Marine and Oceanic Sediments, The Geochemistry of Manganese and Manganese Nodules in the Ocean. Springer, pp. 83-94.

Baturin, G., 2010. Element composition of ferromanganese concretions in the Black Sea. Oceanology 50, 83-92.

Baturin, G., Gorshkov, A., Magazina, L., Bogdanova, O.Y., 2002. Structure and composition of ferromanganese-phosphate nodules from the Black Sea. Lithol. Mineral Resour. 37, 374-385.

Baturin, G.N., Dobretsova, I.G., Dubinchuk, V.T., 2014. Hydrothermal manganese mineralization in the Peterbourgskoye ore field (North Atlantic). Oceanology 54, $222-230$
Bau, M., Koschinsky, A., Dulski, P., Hein, J., 1996. Comparison of the partitioning behaviours of yttrium, rare earth elements, and titanium between hydrogenetic marine ferromanganese crusts and seawater. Geochim. Cosmochim. Acta 60, 1709-1725.

Bau, M., Schmidt, K., Koschinsky, A., Hein, J., Kuhn, T., Usui, A., 2014. Discriminating between different genetic types of marine ferro-manganese crusts and nodules based on rare earth elements and yttrium. Chem. Geol. 381, 1-9.

Bolton, B.R., Both, R., Exon, N.F., Hamilton, T.F., Ostwald, J., Smith, J.D., 1988. Geochemistry and mineralogy of seafloor hydrothermal and hydrogenetic Mn oxide deposits from the Manus Basin and Bismarck Archipelago region of the southwest Pacific Ocean. Mar. Geol. 85, 65-87.

Bonatti, E., Fisher, D.E., Joensuu, O., Rydell, H.S., Beyth, M., 1972. Iron-manganesebarium deposit from the northern Afar Rift (Ethiopia). Econ. Geol. 67, 717-730.

Briais, A., Patriat, P., Tapponnier, P., 1993. Updated interpretation of magnetic anomalies and seafloor spreading stages in the South China Sea: implications for the Tertiary tectonics of Southeast Asia. J. Geophys. Res.: Solid Earth 98, 6299-6328.

Broecker, W.S., Peng, T.-H., Beng, Z., 1982. Tracers in the Sea. Lamont-Doherty Geological Observatory, Columbia University, Palisades, N.Y. p. 690.

Brumsack, H.-J., 1989. Geochemistry of recent TOC-rich sediments from the Gulf of California and the Black Sea. Geol. Rundschau 78, 851-882.

Canet, C., Anadón, P., Alfonso, P., Prol-Ledesma, R.M., Villanueva-Estrada, R.E., García-Vallès, M., 2013. Gas-seep related carbonate and barite authigenic mineralization in the northern Gulf of California. Mar. Petrol. Geol. 43, 147-165.

Chan, L.-H., Hein, J.R., 2007. Lithium contents and isotopic compositions of ferromanganese deposits from the global ocean. Deep Sea Res. Part II 54, 1147-1162.

Chan, L., Edmond, J., Stallard, R., Broecker, W., Chung, Y., Weiss, R., Ku, T., 1976. Radium and barium at GEOSECS stations in the Atlantic and Pacific. Earth Planet. Sci. Lett. 32, 258-267.

Chandnani, M., Gupta, D.K., Singh, R., Singh, P., Baidya, S., Banakar, V., 2012. Compositional variation recorded in deep-sea ferromanganese deposits of the Central Indian Ocean. Curr. Sci. 103, 540-546.

Chen, C.S., Lai, Z.G., Beardsley, R.C., Xu, Q.C., Lin, H.C., Viet, N.T., 2012. Current separation and upwelling over the southeast shelf of Vietnam in the South China Sea. J. Geophys. Res.: Oceans 117, C03033.

Chen, D.F., Huang, Y.Y., Yuan, X.L., Cathles, L.M., 2005. Seep carbonates and preserved methane oxidizing archaea and sulfate reducing bacteria fossils suggest recent gas venting on the seafloor in the Northeastern South China Sea. Mar. Petrol. Geol. 22, 613-621.

Chen, H., Xie, X.N., Van Rooij, D., Vandorpe, T., Su, M., Wang, D.X., 2014. Depositional characteristics and processes of alongslope currents related to a seamount on the northwestern margin of the Northwest Sub-Basin, South China Sea. Mar. Geol. 355, 36-53.

Chen, Y.-L.L., Chen, H.-Y., 2006. Seasonal dynamics of primary and new production in the northern South China Sea: The significance of river discharge and nutrient advection. Deep Sea Res. Part I: Oceanogr. Res. Papers 53, 971-986.

Chen, Y.W., Cui, X.T., 1998. Isotope Geochemistry of the Nansha Islands Sea Area. Science Press, Beijing (in Chinese)

Chiu, J.K., Liu, C.S., 2008. Comparison of sedimentary processes on adjacent passive and active continental margins offshore of SW Taiwan based on echo character studies. Basin Res. 20, 503-518.

Chung, S.-L., Cheng, H., Jahn, B.-M., O’Reilly, S.Y., Zhu, B., 1997. Major and trace element, and $\mathrm{Sr}-\mathrm{Nd}$ isotope constraints on the origin of Paleogene volcanism in South China prior to the South China Sea opening. Lithos 40, 203-220.

Chung, Y., Chang, H.C., Hung, G.W., 2004. Particulate flux and ${ }^{210} \mathrm{~Pb}$ determined on the sediment trap and core samples from the northern South China Sea. Continental Shelf Res. 24, 673-691.

Conrad, T., Hein, J.R., Paytan, A., Clague, D.A., in press. Formation of Fe-Mn crusts within a continental margin environment. Ore Geol. Rev. (in press)

Cronan, D., 1977. Deep-sea nodules: distribution and geochemistry. Mar. Manganese Deposits 15, 11-44.

Dekov, V.M., Scholten, J.C., Botz, R., Garbe-Schönberg, C.D., Stoffers, P., 2007. Fe-Mn(hydr)oxide-carbonate crusts from the Kebrit Deep, Red Sea: Precipitation at the seawater/brine redoxcline. Mar. Geol. 236, 95-119.

Diáz-del-Rio, V., Somoza, L., Martr, J., Mata, M., Delgado, A., Hernandez-Molina, F., Lunar, R., Martí, J., Maestro, A., Fernández-Puga, M., León, R., 2003. Vast fields of hydrocarbon-derived carbonate chimneys related to the accretionary wedge/ olistostrome of the Gulf of Cadiz. Mar. Geol. 195, 177-200.

Dippner, J.W., Nguyen, K.V., Hein, H., Ohde, T., Loick, N., 2007. Monsoon-induced upwelling off the Vietnamese coast. Ocean Dyn. 57, 46-62.

Dymond, J., Lyle, M., Finney, B., Piper, D.Z., Murphy, K., Conard, R., Pisias, N., 1984. Ferromanganese nodules from MANOP Sites $\mathrm{H}, \mathrm{S}$, and $\mathrm{R}-$ Control of mineralogical and chemical composition by multiple accretionary processes. Geochim. Cosmochim. Acta 48, 931-949.

Ergin, M., 1994. Possible sources and mechanisms of manganese enrichment in the deep-sea sediments of the Marmara Trough depressions (NE-Mediterranean, Turkey). Oceanol. Acta 17, 535-546.

Fang, G.H., Wang, G., Fang, Y., Fang, W.D., 2012. A review on the South China Sea western boundary current. Acta Oceanol. Sin. 31, 1-10.

Feng, D., Chen, D.F., 2015. Authigenic carbonates from an active cold seep of the northern South China Sea: new insights into fluid sources and past seepage activity. Deep Sea Res. Part II: Top. Stud. Oceanogr. 122, 74-83.

Feng, D., Chen, D.F., Roberts, H.H., 2009. Petrographic and geochemical characterization of seep carbonate from Bush Hill (GC 185) gas vent and hydrate site of the Gulf of Mexico. Mar. Petrol. Geol. 26, 1190-1198. 
Feng, D., Cheng, M., Kiel, S., Qiu, J.-W., Yang, Q.H., Zhou, H.Y., Peng, Y.B., Chen, D.F., 2015. Using Bathymodiolus tissue stable carbon, nitrogen and sulfur isotopes to infer biogeochemical process at a cold seep in the South China Sea. Deep Sea Res. Part I: Oceanogr. Res. Papers 104, 52-59.

Ge, L., Jiang, S.-Y., Swennen, R., Yang, T., Yang, J.-H., Wu, N.-Y., Liu, J., Chen, D.-H. 2010. Chemical environment of cold seep carbonate formation on the northern continental slope of South China Sea: evidence from trace and rare earth element geochemistry. Mar. Geol. 277, 21-30.

Glasby, G., Emelyanov, E., Zhamoida, V., Baturin, G., Leipe, T., Bahlo, R., Bonacker, P., 1997. Environments of formation of ferromanganese concretions in the Baltic Sea: a critical review. Geol. Soc., London, Special Publ. 119, 213-237.

Gong, C.L., Wang, Y.M., Peng, X.C., Li, W.G., Qiu, Y., Xu, S., 2012. Sediment waves on the South China Sea Slope off southwestern Taiwan: implications for the intrusion of the Northern Pacific Deep Water into the South China Sea. Mar. Petrol. Geol. 32, 95-109.

Gong, C.L., Wang, Y.M., Xu, S., Pickering, K.T., Peng, X.C., Li, W.G., Yan, Q., 2015. The northeastern South China Sea margin created by the combined action of downslope and along-slope processes: processes, products and implications for exploration and paleoceanography. Mar. Petrol. Geol. 64, 233-249.

González, F.J., Somoza, L., Lunar, R., Martínez-Frías, J., Martín Rubí, J., Torres, T., Ortiz, J., Díaz-del-Río, V., 2007. Fe-Mn nodules associated with hydrocarbon seeps: a new discovery in the Gulf of Cadiz (eastern central Atlantic). Episodes 30, 187-196.

González, F.J., Somoza, L., Lunar, R., Martínez-Frías, J., Rubí, J., Torres, T., Ortiz, J., Díaz-del-Río, V., 2010. Internal features, mineralogy and geochemistry of ferromanganese nodules from the Gulf of Cadiz: the role of the Mediterranean Outflow Water undercurrent. J. Mar. Syst. 80, 203-218.

González, F.J., Somoza, L., Lunar, R., Martínez-Frías, J., Rubí, J.M., Torres, T., Ortiz, J., Diaz-del-Río, V., Pinheiro, L., Magalhães, V., 2009. Hydrocarbon-derived ferromanganese nodules in carbonate-mud mounds from the Gulf of Cadiz: mud-breccia sediments and clasts as nucleation sites. Mar. Geol. 261, 64-81.

González, F.J., Somoza, L., Hein, J.R., Medialdea, T., León, R., Urgorri, V., Reyes, J., Martín-Rubí, J.A., 2016. Phosphorites, Co-rich Mn nodules, and Fe-Mn crusts from Galicia Bank, NE Atlantic: reflections of Cenozoic tectonics and paleoceanography. Geochem., Geophys., Geosyst. 17, 346-374.

González, F.J., Somoza, L., León, R., Medialdea, T., Torres, T., Ortiz, J.E., Lunar, R., Martinez-Frias, J., Merinero, R., 2012. Ferromanganese nodules and microhardgrounds associated with the Cadiz Contourite Channel (NE Atlantic): palaeoenvironmental records of fluid venting and bottom currents. Chem. Geol. 310, 56-78.

Halbach, P., Scherhag, C., Hebisch, U., Marchig, V., 1981. Geochemical and mineralogical control of different genetic types of deep-sea nodules from the Pacific Ocean. Mineral. Deposita 16, 59-84.

Han, X.Q., Suess, E., Liebetrau, V., Eisenhauer, A., Huang, Y.Y., 2014. Past methane release events and environmental conditions at the upper continental slope of the South China Sea: constraints by seep carbonates. Int. J. Earth Sci. 103, 18731887.

Han, X.Q., Yang, K.H., Huang, Y.Y., 2013. Origin and nature of cold seep in northeastern Dongsha area, South China Sea: evidence from chimney-like seep carbonates. Chinese Sci. Bull. 58, 3689-3697.

He, E.Y., Zhao, M.H., Qiu, X.L., Sibuet, J.-C., Wang, J., Zhang, J.Z., 2016. Crustal structure across the post-spreading magmatic ridge of the East Sub-basin in the South China Sea: tectonic significance. J. Asian Earth Sci. 121, 139-152.

He, L.B., 1991. Geochemical characteristics of Fe-Mn nodules and crusts from the Mariana Ridge and the West Philippine Basin. Chinese Sci. Bull. 36, 1190-1193 (in Chinese with English abstract).

He, Y.L., Xie, X.N., Kneller, B.C., Wang, Z.F., Li, X.S., 2013. Architecture and controlling factors of canyon fills on the shelf margin in the Qiongdongnan Basin, northern South China Sea. Mar. Petrol. Geol. 41, 264-276.

Hein, J.R., Conrad, T., Frank, M., Christl, M., Sager, W., 2012. Copper-nickel-rich, amalgamated ferromanganese crust-nodule deposits from Shatsky Rise, NW Pacific. Geochem., Geophys., Geosyst. 13, Q10022.

Hein, J.R., Koschinsky, A., Bau, M., Manheim, F., Kang, J.-K., Roberts, L., 2000. Cobaltrich ferromanganese crusts in the Pacific. In: Cronan, D.S. (Ed.), Handbook of Marine Mineral Deposits, CRC Marine Science Series, vol. 17. CRC Press, Boca Raton, Florida, pp. 239-279.

Hein, J.R., Schulz, M., Jung-Keuk, K., 1990. Insular and submarine ferromanganese mineralization of the Tonga-Lau region. Mar. Mining 9, 305-354.

Hein, J.R., Conrad, T.A., Staudigel, H., 2010. Seamount mineral deposits: a source of rare metals for high-technology industries. Oceanography 23, 184-189.

Hein, J.R., Koschinsky, A., 2013. Deep-ocean ferromanganese crusts and nodules. In: Holland, H.D., Turekian, K.K. (Eds.), Treatise on Geochemistry, second ed., vol. 13. Elsevier, Oxford, pp. 273-291 (Chapter 11).

Hein, J.R., Koschinsky, A., Halbach, P., Manheim, F.T., Bau, M., Kang, J.-K., Lubick, N., 1997. Iron and manganese oxide mineralization in the Pacific. In: Nicholson, K., Hein, J.R., Bühn, B., Dasgupta, S. (Eds.), Manganese Mineralization: Geochemistry and Mineralogy of Terrestrial and Marine Deposits, vol. 119. Geological Society of London Special Publication, London, pp. 123-138.

Hein, J.R., Koschinsky, A., McIntyre, B.R., 2005. Mercury-and silver-rich ferromanganese oxides, southern California borderland: deposit model and environmental implications. Econ. Geol. 100, 1151-1168.

Hein, J.R., Mizell, K., Koschinsky, A., Conrad, T.A., 2013. Deep-ocean mineral deposits as a source of critical metals for high-and green-technology applications: comparison with land-based resources. Ore Geol. Rev. 51, 1-14.
Hein, J.R., Koschinsky, A., Mikesell, M., Mizell, K., Glenn, C.R., Wood, R., 2016. Marine phosphorites as potential resources for heavy rare earth elements and yttrium. Minerals 6, 88.

Hernández-Molina, F.J., Llave, E., Stow, D., García, M., Somoza, L., Vázquez, J.T., Lobo, F. Maestro, A. del Río, V.D., León, R., 2006. The contourite depositional system of the Gulf of Cadiz: a sedimentary model related to the bottom current activity of the Mediterranean outflow water and its interaction with the continental margin. Deep Sea Res. Part II: Top. Stud. Oceanogr. 53, 1420-1463.

Hernández-Molina, F.J., Paterlini, M., Somoza, L., Violante, R., Arecco, M.A., de Isasi, M., Rebesco, M., Uenzelmann-Neben, G., Neben, S., Marshall, P., 2010. Giant mounded drifts in the Argentine Continental Margin: origins, and global implications for the history of thermohaline circulation. Mar. Petrol. Geol. 27, $1508-1530$.

Hlawatsch, S., Garbe-Schönberg, C., Lechtenberg, F., Manceau, A., Tamura, N., Kulik, D., Kersten, M., 2002. Trace metal fluxes to ferromanganese nodules from the western Baltic Sea as a record for long-term environmental changes. Chem. Geol. 182, 697-709.

Hucrrns, J.M., ClvrnnoN, M., MlnuNo, A.N., 1991. Rare-earth-element ordering and structural variations in natural rare-earth-bearing apatites. Am. Mineral. 76, 1165-1173.

Hughes, J.M., Rakovan, J.F., 2015. Structurally robust, chemically diverse: apatite and apatite supergroup minerals. Elements 11, 165-170.

Jauhari, P., 1989. Variability of Mn, Fe, $\mathrm{Ni}, \mathrm{Cu}$ and $\mathrm{Co}$ in manganese nodules from the Central Indian Ocean Basin. Mar. Geol. 86, 237-242.

Josso, P., Pelleter, E., Pourret, O., Fouquet, Y., Etoubleau, J., Cheron, S., Bollinger, C., in press. A new discrimination scheme for oceanic ferromanganese deposits using high field strength and rare earth elements. Ore Geol. Rev. (in press)

Koschinsky, A., Halbach, P., 1995. Sequential leaching of marine ferromanganese precipitates: genetic implications. Geochim. Cosmochim. Acta 59, 5113-5132.

Koshinesky, A., Hein, J.R., 2003. Uptake of elements from seawater by ferromanganese crusts: solid phase association and seawater speciation. Mar Geol. 98, 331-351.

Kuang, Z., Zhong, G., Wang, L., Guo, Y., 2014. Channel-related sediment waves on the eastern slope offshore Dongsha Islands, northern South China Sea. J. Asian Earth Sci. 79, 540-551.

Kudrass, H., Wiedicke, M., Cepek, P., Kreuzer, H., Müller, P., 1986. Mesozoic and Cainozoic rocks dredged from the South China Sea (Reed Bank area) and Sulu Sea and their significance for plate-tectonic reconstructions. Mar. Petrol. Geol. 3, 19-30.

Kuhn, T., Rühlemann, C., Wiedicke-Hombach, M., 2012. Developing a Strategy for the Exploration of Vast Seafloor Areas for Prospective Manganese Nodule Fields. Marine Minerals: Finding the Right Balance of Sustainable Development and Environmental Protection. The Underwater Mining Institute.

Lüdmann, T., Wong, H.K., Berglar, K., 2005. Upward flow of North Pacific Deep Wate in the northern South China Sea as deduced from the occurrence of drift sediments. Geophys. Res. Lett. 32, L05614.

Li, H., Wang, Y.M., Zhu, W.L., Xu, Q., He, Y., Tang, W., Zhuo, H.T., Wang, D., Wu, J.P., Li, D., 2013a. Seismic characteristics and processes of the Plio-Quaternary unidirectionally migrating channels and contourites in the northern slope of the South China Sea. Mar. Petrol. Geol. 43, 370-380.

Li, L., Lei, X.H., Zhang, X., Sha, Z.B., 2013b. Gas hydrate and associated free gas in the Dongsha Area of northern South China Sea. Mar. Petrol. Geol. 39, 92-101.

Li, L., Qu, T.D., 2006. Thermohaline circulation in the deep South China Sea basin inferred from oxygen distributions. J. Geophys. Res.: Oceans 111, C05017.

Li, S.L., Gong, C.L., 2016. Flow dynamics and sedimentation of lateral accretion packages in sinuous deep-water channels: a 3D seismic case study from the northwestern South China Sea margin. J. Asian Earth Sci. 124, 233-246.

Liang, M.T., Chen, S.M., Wu, B.H., Li, S.J., 1988. A preliminary study on characteristics on geochemistry of manganese nodules from the basin and continental slope of the South China Sea. J. Tropic. Oceanogr. 3, 11-18 (in Chinese with English abstract).

Liang, H.F., Yao, D., Liang, D.H., Liu, X.B., 1991. Geochemistry of polymetallic crust from JianFeng Seamount, South China Sea. Mar. Geol. Quatern. Geol. 11, 49-57 (in Chinese with English abstract).

Lin, Z.H., Ji, F.W., Zhang, F.Y., Lin, X.T., Shi, Z.B., 2003. Characteristics and origin of ferromanganese nodules from the northeastern continental slope of the South China Sea. Mar. Geol. Quatern. Geol. 23, 7-12 (in Chinese with English abstract).

Ling, H.F., Burton, K., O’Nions, R., Kamber, B., Von Blanckenburg, F., Gibb, A., Hein, J. R., 1997. Evolution of $\mathrm{Nd}$ and $\mathrm{Pb}$ isotopes in Central Pacific seawater from ferromanganese crusts. Earth Planet. Sci. Lett. 146, 1-12.

Liu, Z.F., Tuo, S.T., Colin, C., Liu, J.T., Huang, C.-Y., Selvaraj, K., Chen, C.-T.A., Zhao, Y.L. Siringan, F.P., Boulay, S., 2008. Detrital fine-grained sediment contribution from Taiwan to the northern South China Sea and its relation to regional ocean circulation. Mar. Geol. 255, 149-155.

Liu, Z.F., Zhao, Y.L., Colin, C. Stattegger, K. Wiesner, M.G, Huh, C.-A., Zhang Y.W. Li, X.J., Sompongchaiyakul, P., You, C.-F., 2015. Source-to-Sink transport processes of fluvial sediments in the South China Sea. Earth-Sci. Rev.

Luo, Y.L., Feng, W.W., Lin, H.Z., 1994. Bottom sediment types and depositional characteristics of sediments of the South China Sea. Tropic Oceanol. 1 (in Chinese with English abstract).

Ma, M.L., Chai, Z.F., Mao, X.Y., Zhou, Y.Q., Ma, J.G., 1987. Neutron activation studies on the ferromanganese sediments of the South China Sea. Donghai Mar. Sci. Z1 (in Chinese with English abstract).

Magalhães, V.H., Pinheiro, L.M., Ivanov, M.K., Kozlova, E., Blinova, V., Kolganova, J., Vasconcelos, C., McKenzie, J.A., Bernasconi, S.M., Kopf, A.J., 2012. Formation 
processes of methane-derived authigenic carbonates from the Gulf of Cadiz. Sedimentary Geol. 243, 155-168.

Manheim, F., Lane-Bostwick, C., 1988. Cobalt in ferromanganese crusts as a monitor of hydrothermal discharge on the Pacific sea floor. Nature 335, 59-62.

Marino, E., González, F.J., Somoza, L., Lunar, R., Ortega, L., Vázquez, J.T., Reyes, J. Bellido, E., in press. Strategic and rare elements in Cretaceous-Cenozoic cobaltrich ferromanganese crusts from seamounts in the Canary Island Seamount Province (northeastern tropical Atlantic). Ore Geol. Rev. (in press)

McDonnell, S.L., Max, M.D., Cherkis, N.Z., Czarnecki, M.F., 2000. Tectonosedimentary controls on the likelihood of gas hydrate occurrence near Taiwan. Mar. Petrol. Geol. 17, 929-936.

McLennan, S., 1989. Rare earth elements in sedimentary rocks; influence of provenance and sedimentary processes. Rev. Mineral. Geochem. 21, 169-200.

Medialdea, T., Somoza, L., Pinheiro, L.M., Fernández-Puga, M., Vázquez, J., León, R. Ivanov, M., Magalhaes, V., Díaz-del-Río, V., Vegas, R., 2009. Tectonics and mud volcano development in the Gulf of Cádiz. Mar. Geol. 261, 48-63.

Milliman, J.D., Farnsworth, K.L., 2011. River Discharge to the Coastal Ocean: A Global Synthesis. Cambridge University Press.

Mukhopadhyay, R., Iyer, S.D., Ghosh, A.K., 2003. The Indian Ocean Nodule Field: petrotectonic evolution and ferromanganese deposits. Earth-Sci. Rev. 60, 67130.

Nath, B.N., Balaram, V., Sudhakar, M., Plüger, W., 1992. Rare earth element geochemistry of ferromanganese deposits from the Indian Ocean. Mar. Chem. 38, 185-208.

Pattan, J., Parthiban, G., 2011. Geochemistry of ferromanganese nodule-sediment pairs from Central Indian Ocean Basin. J. Asian Earth Sci. 40, 569-580.

Pattan, J., Pearce, N., Parthiban, G., Smith, V., Mudholkar, A.V., Rao, N.R., 2013. The origin of ferro-manganese oxide coated pumice from the Central Indian Ocean Basin. Quatern. Int. 313, 230-239.

Paytan, A., Griffith, E.M., 2007. Marine barite: recorder of variations in ocean export productivity. Deep Sea Res. Part II 54, 687-705.

Piper, D.Z., 1974. Rare earth elements in ferromanganese nodules and other marine phases. Geochim. Cosmochim. Acta 38, 1007-1022.

Qu, T.D., Du, Y., Sasaki, H., 2006a. South China Sea throughflow: a heat and freshwater conveyor. Geophys. Res. Lett. 33, L23617.

Qu, T.D., Girton, J.B., Whitehead, J.A., 2006b. Deepwater overflow through Luzon strait. J. Geophys. Res.: Oceans 1978-2012, 111.

Rao, V.P., 1987. Mineralogy of polymetallic nodules and associated sediments from the Central Indian Ocean Basin. Mar. Geol. 74, 151-157.

Ren, X.W. Glasby, G., Liu, J.H., Shi, X.F., Yin, J.W., 2007. Fine-scale compositional variations in a Co-rich Mn crust from the Marcus-Wake Seamount cluster in the western Pacific based on electron microprobe analysis (EMPA). Mar. Geophys Res. 28, 165-182.

Reyss, J., Marchig, V., Ku, T., 1982. Rapid growth of a deep-sea manganese nodule.

Rona, P.A., 2008. The changing vision of marine minerals. Ore Geol. Rev. 33, 618666.

Shan, L.F., 1984. Study of ferromanganese nodules from different places of production. Mar. Geol. Quatern. Geol. 1, 008 (in Chinese with English abstract).

Shao, L., Li, X.J., Geng, J.H., Pang, X., Lei, Y.C., Qiao, P.J., Wang, L.L., Wang, H.B., 2007. Deep water bottom current deposition in the northern South China Sea. Sci. China Series D: Earth Sci. 50, 1060-1066.

Shaw, P.-T., Chao, S.-Y., 1994. Surface circulation in the South China Sea. Deep Sea Res. Part I: Oceanogr. Res. Papers 41, 1663-1683.

Somoza, L., Diaz-del-Rio, V., Leon, P., Ivanov, M., Fernandez-Puga, M.C., Gardner, J. M., Hernández-Molina, F.J., Pinheiro, L.M., Rodero, J., Lobato, A., Maestro, A. Vázquez, J.T., Medialdea, T., Fernández-Salas, L.M., 2003. Seabed morphology and hydrocarbon seepage in the Gulf of Cádiz mud volcano area: acoustic imagery, multibeam and ultra-high resolution seismic data. Mar. Geol. 195, $153-176$.

Somoza, L., Medialdea, T., León, R., Ercilla, G., Vázquez, J.T., Farran, M., HernándezMolina, J., González, J., Juan, C., Fernández-Puga, M.C., 2012. Structure of mud volcano systems and pockmarks in the region of the Ceuta Contourite Depositional System (Western Alborán Sea). Mar. Geol. 332-334, 4-26.

Stow, D.A., Faugères, J.-C., Howe, J.A., Pudsey, C.J., Viana, A.R., 2002. Bottom currents, contourites and deep-sea sediment drifts: current state-of-the-art. Geological Soc., London, Memoirs 22, 7-20.

Sudhakar, M., 1989. Ore grade manganese nodules from the central Indian basin an evaluation. Mar. Mining 8, 201-214.

Sun, Q., Wu, S., Cartwright, J., Wang, S., Lu, Y., Chen, D., Dong, D., 2014. Neogene igneous intrusions in the northern South China Sea: evidence from highresolution three dimensional seismic data. Mar. Petrol. Geol. 54, 83-95.

Suo, Y.H., Li, S.Z., Yu, S., Somerville, I.D., Liu, X., Zhao, S.J., Dai, L.M., 2014. Cenozoic tectonic jumping and implications for hydrocarbon accumulation in basins in the East Asia Continental Margin. J. Asian Earth Sci. 88, 28-40.

Tang, D.L., Kawamura, H., Van Dien, T., Lee, M., 2004. Offshore phytoplankton biomass increase and its oceanographic causes in the South China Sea. Mar. Ecol. Progr. Ser. 268, 31-41.

Taylor, B., Hayes, D.E., 1983. Origin and history of the South China Sea basin. The Tectonic and Geologic Evolution of Southeast Asian Seas and Islands: Part 2 Geophs. Monograph Ser, AGU, Washington, D.C. 27, 23-56.

Tian, J.W., Yang, Q.X., Liang, X.F., Xie, L.L., Hu, D.X., Wang, F., Qu, T.D., 2006 Observation of Luzon Strait transport. Geophys. Res. Lett. 33, L19607.

Tian, J.W., Yang, Q.X., Zhao, W., 2009. Enhanced diapycnal mixing in the South China Sea. J. Phys. Oceanogr. 39, 3191-3203.

Tong, H.P., Feng, D., Cheng, H., Yang, S.X., Wang, H.B., Min, A.G., Edwards, R.L., Chen, Z., Chen, D.F., 2013. Authigenic carbonates from seeps on the northern continental slope of the South China Sea: new insights into fluid sources and geochronology. Mar. Petrol. Geol. 43, 260-271.

Torres, M.E., Bohrmann, G., Dubé, T.E., Poole, F.G., 2003. Formation of modern and Paleozoic stratiform barite at cold methane seeps on continental margins. Geology 31, 897-900.

Torres, M.E., Bohrmann, G., Suess, E., 1996. Authigenic barites and fluxes of barium associated with fluid seeps in the Peru subduction zone. Earth Planet. Sci. Lett. $144,469-481$.

Tu, K., Flower, M.F., Carlson, R.W., Xie, G.H., Chen, C.-Y., Zhang, M., 1992. Magmatism in the South China Basin: 1. Isotopic and trace-element evidence for an endogenous Dupal mantle component. Chem. Geol. 97, 47-63.

Vanneste, H., James, R.H., Kelly-Gerreyn, B.A., Mills, R.A., 2013. Authigenic barite records of methane seepage at the Carlos Ribeiro mud volcano (Gulf of Cadiz). Chem. Geol. 354, 42-54.

Verlaan, P.A., Cronan, D.S., Morgan, C.L., 2004. A comparative analysis of compositional variations in and between marine ferromanganese nodules and crusts in the South Pacific and their environmental controls. Progr. Oceanogr. 63, 125-158.

von Stackelberg, U., 2000. Manganese nodules of the Peru Basin. In: Cronan, D.S (Ed.), Handbook of Marine Mineral Deposits. CRC Press, Boca Raton, FL, pp. $197-$ 238

Wang, G.H., Xie, S.P., Qu, T.D., Huang, R.X., 2011. Deep South China Sea circulation. Geophys. Res. Lett. 38, L05601.

Wang, H., Yuan, S., Gao, H., 2010. The contourite system and the framework of contour current circulation in the South China Sea. Geo-Temas 11, 189-190.

Wang, P.X., Li, Q.Y., 2009. History of the South China Sea-A Synthesis. The South China Sea. Springer, pp. 487-496.

Wang, S.H., Yan, W., Chen, Z., Zhang, N., Chen, H., 2014. Rare earth elements in cold seep carbonates from the southwestern Dongsha area, northern South China Sea. Mar. Petrol. Geol. 57, 482-493.

Wang, X.J., Chen, Y.W., Wu, M.Q., 1984. Rare earths and trace elements geochemistry of Fe-Mn concentrations and substance sources. Ocean and Lake 6, 501-514 (in Chinese with English abstract).

Wang, X.J., Wu, M.Q., Liang, D.H., Yin, A.W., 1985. Some geochemical characteristics of basalts in the South China Sea. Chinese J. Geochem. 4, 380-390 (in Chinese with English abstract)

Wang, X.J., Chen, Y.W., Wu, M.Q., 1986. Geochemistry of rare and trace elements in ferromanganese nodules and their genesis. Chin. J. Ocean. Limnol. 4, 211-226 (in Chinese with English abstract).

Wang, Y.J., Han, X.Q. Luo, Z.H., Qiu, Z., Ding, W., Li, J., Gao, S., Chen, R., 2009. Late Miocene magmatism and evolution of Zhenbei-Huangyan Seamount in the South China Sea: evidence from petrochemistry and chronology. Acta Oceanol. Sin. 31, 93-101.

Wegorzewski, A.V., Kuhn, T., 2014. The influence of suboxic diagenesis on the formation of manganese nodules in the Clarion Clipperton nodule belt of the Pacific Ocean. Mar. Geol. 357, 123-138.

Wyrtki, K., 1961. Physical oceanography of the southeast Asian waters. Naga Rep. Scripps Institution of Oceanography, La Jolla, Calif, 2, 195 pp.

Xie, S.P., Xie, Q., Wang, D.X., Liu, W.T., 2003. Summer upwelling in the South China Sea and its role in regional climate variations. J. Geophys. Res.: Oceans 108 (C8), 3261.

Xu, Y.G., Wei, J.X., Qiu, H.N., Zhang, H.H., Huang, X.L., 2012. Opening and evolution of the South China Sea constrained by studies on volcanic rocks: preliminary results and a research design. Chinese Sci. Bull. 57, 3150-3164.

Xu, Z.K., Li, A., Jiang, F.Q., Meng, Q., Liu, J., 2006. Characteristics and origin of the new-type ferromanganese crusts from deepwater areas of the East Philippine Sea. Mar. Geol. Quatern. Geol. 26, 91-98.

Yan, P., Deng, H., Liu, H.L., Zhang, Z.R. Jiang, Y.K., 2006. The temporal and spatial distribution of volcanism in the South China Sea region. J. Asian Earth Sci. 27, 647-659.

Yan, Q.S., Castillo, P. Shi, X.F., Wang L.L, Liao, L, Ren, J.B., 2015. Geochemistry and petrogenesis of volcanic rocks from Daimao Seamount (South China Sea) and their tectonic implications. Lithos 218, 117-126.

Yan, Q.S., Shi, X.F., Castillo, P.R., 2014. The late Mesozoic-Cenozoic tectonic evolution of the South China Sea: a petrologic perspective. J. Asian Earth Sci. $85,178-201$.

Yan, Q.S., Shi, X.F., Wang, K.S., Bu, W.R., Xiao, L., 2008. Major element, trace element, and $\mathrm{Sr}, \mathrm{Nd}$ and $\mathrm{Pb}$ isotope studies of Cenozoic basalts from the South China Sea. Sci. China Series D: Earth Sci. 51, 550-566.

Yao, B.C., Zeng, W.J., Hayes, D.E., Spangler, S., 1994. The Geological Memoir of South China Sea Surveyed jointly by China and the U.S.A. The Press of Chinese Geological University, Wuhan (in Chinese).

Yao, B.C., 1996. Tectonic evolution of the South China Sea in Cenozoic. Mar. Geol. Quatern. Geol. 16, 1-13 (in Chinese with English abstract).

Zhamoida, V., Butylin, W., Glasby, G., Popova, I., 1996. The nature of ferromanganese concretions from the Eastern Gulf of Finland, Baltic Sea. Mar. Georesour. Geotechnol. 14, 161-176.

Zhamoida, V., Grigoriev, A., Gruzdov, K., Ryabchuk, D., 2007. The influence of ferromanganese concretions-forming processes in the eastern Gulf of Finland on the marine environment. Geol. Surv. Finland Special Papers 45, 21-32.

Zhang, G., Liang, J., Lu, J.a., Yang, S., Zhang, M., Holland, M., Schultheiss, P., Su, X., Sha, Z., Xu, H., Gong, Y., Fu, S., Wang, L., Kuang, Z., 2015. Geological features, controlling factors and potential prospects of the gas hydrate occurrence in the east part of the Pearl River Mouth Basin, South China Sea. Mar. Petrol. Geol. 67, 356-367. 
Zhang, Z., Du, Y., Wu, C., Fang, N., Yang, S., Liu, J., Song, C., 2013. Growth of a polymetallic nodule from the northwestern continental margin of the South China Sea and its response to changes in the paleoceanographical environment of the Late Cenozoic. Sci. China Earth Sci. 56, 453-463.

Zhang, Z.G., Du, Y., Gao, L., Zhang, Y., Shi, G., Liu, C.L., Zhang, P., Duan, X., 2012. Enrichment of REEs in polymetallic nodules and crusts and its potential for exploitation. J. Rare Earths 30, 621-626 (in Chinese with English abstract).

Zhao, W., Zhou, C., Tian, J., Yang, Q., Wang, B., Xie, L., Qu, T., 2014. Deep water circulation in the Luzon Strait. J. Geophys. Res.: Oceans 119, 790-804.

Zheng, H.B., Yan, P., 2012. Deep-water bottom current research in the northern South China Sea. Mar. Georesour. Geotechnol. 30, 122-129 (in Chinese with English abstract).
Zhou, H., Xiao, L., Dong, Y., Wang, C., Wang, F., Ni, P., 2009. Geochemical and geochronological study of the Sanshui basin bimodal volcanic rock suite, China: implications for basin dynamics in southeastern China. J. Asian Earth Sci. 34, 178-189.

Zhu, M., Graham, S., Pang X., McHargue, T. 2010. Characteristics of migrating submarine canyons from the middle Miocene to present: implications for paleoceanographic circulation, northern South China Sea. Mar. Petrol. Geol. 27, 307-319. 